\title{
EMBRIOGÊNESE SOMÁTICA DA BANANEIRA (Musa spp): INDUÇÃO, MATURAÇÃO E ANÁLISE MORFO-ANATÔMICA
}

\author{
SILVIA BALBÃO FILIPPI \\ Engenheira Agrônoma
}

Orientadora: Prof ${ }^{a}$. Dr ${ }^{a}$. ADRIANA PINHEIRO MARTINELLI RODRIGUEZ

\begin{abstract}
Dissertação apresentada à Escola Superior de Agricultura "Luiz de Queiroz", Universidade de São Paulo, para obtenção do título de Mestre em Ciências, Área de Concentração: Fisiologia e Bioquímica de Plantas.
\end{abstract}

PIRACICABA

Estado de São Paulo - Brasil

Agosto -2000 


\section{Errata:}

Na pág. 61 , no $1^{\circ}$ parágrafo, onde se lê ... embriōes zigóticos morfologicamente semelhantes a embriões zigóticos de Musa acuminata... leia-se ... embriões somáticos morfologicamente semelhantes a embriões zigóticos de Musa acuminata...

Onde se lê microscopia ótica, leia-se microscopia óptica. 


\section{Dados Internacionais de Catalogação na Publicação (CIP) DIVISÃO DE BIBLIOTECA E DOCUMENTAÇĀO - Campus "Luiz de Oueiroz"/USP}

Filippi, Silvia Balbão.

Embriogênese somática da bananeira (Musaspp) : indução, maturação e análise morfo-anatômica / Silvia Balbão Filippi. - Piracicaba, 2000.

$73 \mathrm{p}$.

Dissertação (mestrado) - - Escola Superior de Agricultura Luiz de Queiroz, 2000. Bibliografia.

1. Banana 2. Cultivo "in vitro" 3. Embriogênese somática 4. Indução 5 . Inflorescência 6. Maturação 7. Regulador de crescimento vegetal 8 . Variedade I. Título 
Aos meus pais, Eduardo Carlos e Ana Maria,

pela minha formação profissional e pessoal,

\section{DEDICO}

A Deus,

pela constante presença na minha vida

\section{OFEREÇO}




\section{AGRADECIMENTOS}

À Profa. Dra. Adriana Pinheiro Martinelli Rodriguez, pela orientação, dedicação, apoio e estímulo à pesquisa, e incentivo profissional. Pela amizade e respeito adquiridos durante todos esses anos de convivência.

À Escola Superior de Agricultura "Luiz de Queiroz" e ao Departamento de Ciências Biológicas, pela possibilidade de realização do curso de Mestrado.

Ao Laboratório de Biotecnologia Vegetal (CENA/USP), onde foram realizados os experimentos.

Ao Conselho Nacional de Desenvolvimento Científico e Tecnológico (CNPq), pela concessão de bolsa de mestrado.

À Fundação de Amparo à Pesquisa do Estado de São Paulo (FAPESP) pelo auxilio financeiro.

Aos professores do curso de Fisiologia e Bioquímica de Plantas, principalmente à Profa. Dra. Beatriz Appezzato-da-Glória, pela atenção, amizade e interesse pelo trabalho desenvolvido, e ao Prof. Dr. Ricardo Ferraz de Oliveira, pelo apoio ao projeto.

À Profa. Beatriz Appezzato-da-Glória, do Depto. de Ciências Biológicas/ESALQ, pela oportunidade de realização de experimento em conjunto.

Ao Prof. Dr. João Alexio Scarpare Filho, do Depto. de Produção Vegetal e à Eng. Agrônoma Selma Borges, pela cessão de mudas e inflorescências.

Ao técnico Paulo Cassieri Neto, pela cessão e colaboração na coleta e limpeza de mudas e infloresc6encias.

À técnica Marli Kazue M. Soares, do Laboratório de Anatomia Vegetal (ESALQ/USP) pela ajuda no preparo de material para microscopia ótica.

Ao João Geraldo Brancalion, do Laboratório de Instrumentação e Informática (CENA/USP), pela colaboração e serviços de computação gráfica. 
À bibliotecária chefe Marilia Henyei (CENA/USP) pela revisão das referências bibliográficas.

Ao Núcleo de Apoio à Pesquisa/Microscopia Eletrônica na Pesquisa Agropecuária - NAP/MEPA (ESALQ/USP), pela utilização dos equipamentos e microscópio eletrônico de varredura.

À técnica Mônica Lanzoni Rossi, pelo auxílio na utilização de equipamento do NAP/MEPA (ESALQ/USP).

Aos amigos Juliano K. Jujisawa e Lilia Pedroso Barbosa, pela ajuda no cultivo de mudas in vitro.

Aos amigos e amigas, Alessandra C.B.A. Monteiro-Hara, Liliane C.L. Stipp, Márcio L. Tomaz, Paulo Celso de Mello Farias, Sandra C. Capaldi Arruda, pela amizade e apoio.

Aos meus pais, por todo o esforço dedicado à minha educação e formação pessoal. Pelo constante apoio e ajuda necessários para a realização desse projeto.

Ao Marcelo Ladeira de Oliveira, pelo respeito, amor e carinho, que nos une nos momentos fáceis e dificeis da vida.

Aos meus irmãos Cecilia, Marcos e Cristina, pela amizade que nos une.

Aos meus sobrinkos Afornso Luis e viter Henrique. 
SUMÁRIO

Página

RESUMO

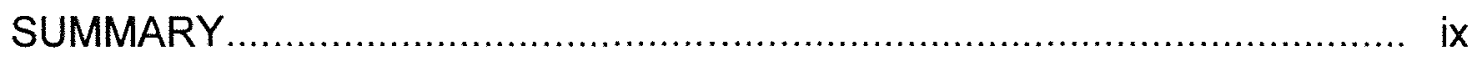

1. INTRODUÇÃO

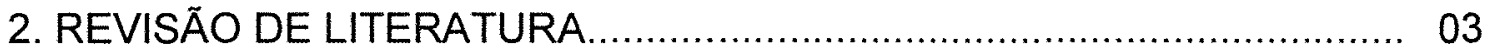

2.1. Cultura da Bananeira (Musa spp) ................................................. 03

2.2. Cultivo in vitro da bananeira.......................................................... 06

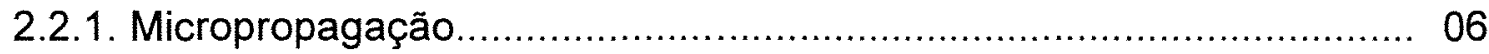

2.2.2. Embriogênese somática em Musa spp....................................... 08

2.3. Fatores que afetam a embriogênese somática.................................. 10

2.4. Histologia e Morfologia............................................................... 17

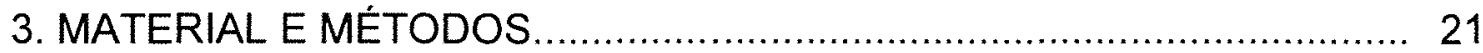

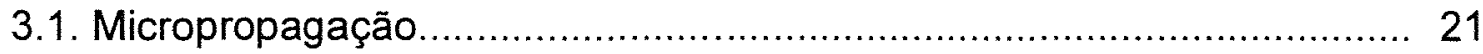

3.2. Embriogênese somática a partir de explantes de ápice vegetativo....... 25

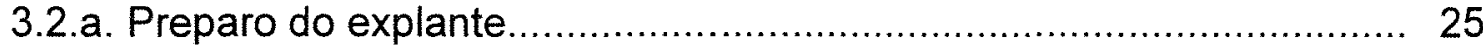

3.2.1. Comparação do efeito de diferentes auxinas na indução de embriogênese somática na cv. Nanicão................................................ 25

3.2.2. Comparação entre diferentes meios de cultura e tempo necessário para indução de embriogênese somática nas cvs. Nanicão e Ouro............. 26

3.2.3. Maturação e germinação dos embriões somáticos......................... 28

3.3. Embriogênese somática a partir de inflorescências funcionalmente masculinas. 


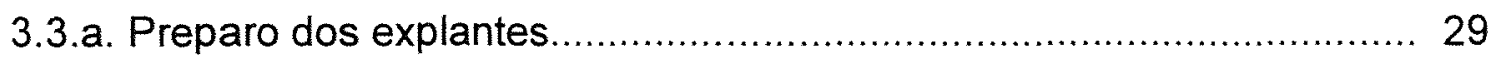

3.3.b. Condições de indução............................................................. 30

3.4. Preparo das amostras para análises microscópicas......................... 31

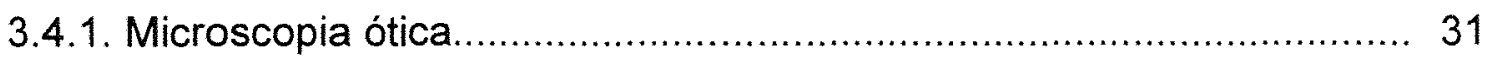

3.4.2. Microscopia eletrônica de varredura.......................................... 32

4. RESULTADOS E DISCUSSÃO ..................................................... 33

4.1. Embriogênese somática a partir de explantes de ápice vegetativo....... 33

4.1.1. Comparação do efeito de diferentes auxinas na indução de embriogênese somática na cv. Nanicão..................................................... 33

4.1.2. Comparação entre diferentes meios de cultura e tempo necessário para indução de embriogênese somática nas cvs. Nanicão e Ouro............. 43

4.1.3. Maturação e germinação dos embriões somáticos........................... 50

4.2. Embriogênese somática a partir de inflorescências funcionalmente

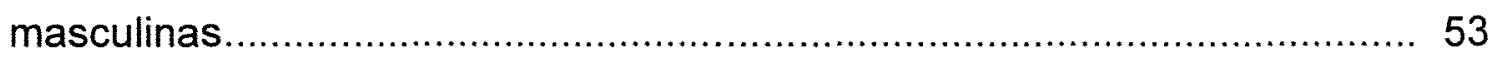

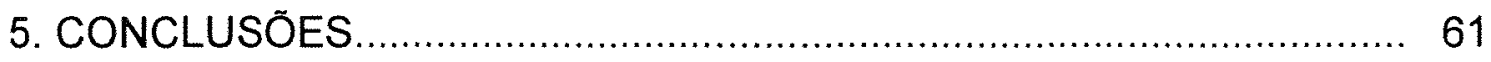

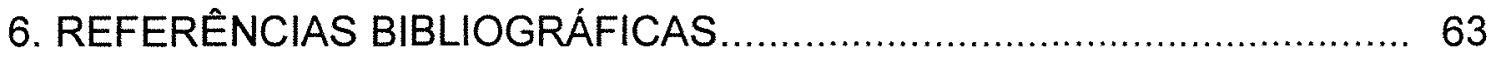




\title{
EMBRIOGÊNESE SOMÁTICA DA BANANEIRA (Musa spp): INDUÇÃO, MATURAÇÃO E ANÁLISE MORFO-ANATÔMICA
}

\author{
Autora: SILVIA BALBÃO FILIPPI \\ Orientadora: Profa. Dra. ADRIANA PINHEIRO MARTINELLI RODRIGUEZ
}

\section{RESUMO}

Este trabalho teve como objetivo a obtenção de embriogênese somática em cultivares brasileiras de bananeira e subsequente conversão dos embriões somáticos em plantas. Estudos desta natureza visam possibilitar trabalhos futuros que envolvam a manipulação genética, para melhoramento desta cultura. O projeto consistiu, primeiramente, na indução de embriogênese somática a partir de ápices vegetativos testando-se: diferentes auxinas (dicamba, picloram, 2,4-D e NAA) em meio MS (Murashige \& Skoog, 1962); três meios de cultura com diferentes razões entre nitrogênio nítrico e amoniacal $\left(\mathrm{NO}_{3}{ }^{-}: \mathrm{NH}_{4}{ }^{+}\right)$; e tempo necessário para permanência do explante no meio de indução. Indução foi obtida, porém, embriões somáticos não converteram-se em plantas. Em seguida, estudou-se o efeito do tratamento de maturação, através de cultivo contendo concentração mais elevada de sacarose $(60 \mathrm{~g} / \mathrm{L})$ ou PEG (polietilenoglicol), na conversão e germinação de embriões somáticos a partir de ápices vegetativos. Alternadamente, foram utilizados explantes de inflorescências masculinas na indução de embriogênese somática. Em todas as 
etapas foram realizadas análises morfo-anatômicas através de microscopia ótica e eletrônica de varredura. $\mathrm{Na}$ indução a partir de ápices vegetativos, as auxinas dicamba e picloram apresentaram formação de estruturas embriogênicas e embriões somáticos, enquanto que as demais apresentaram ausência de resposta embriogênica. Cortes histológicos dos explantes em meio com dicamba, mostraram regiões embriogênicas com formação de próembriões e regiões meristemáticas não organizadas, que possivelmente, originaram estruturas monopolares. Os embriões somáticos eram morfologicamente semelhantes aos embriões zigóticos de Musa acuminata, porém, diferenciação de protoderme, ápices meristemáticos e procâmbio, não foram observados. Entre os três diferentes meios de cultura testados na indução (SH, FN-Lite ou $1 / 2 \mathrm{MS}$ ), o meio $\mathrm{FN}$-Lite e $1 / 2 \mathrm{MS}$, com razão nitrato:amônio de 4:1 e 2:1, respectivamente, apresentaram melhor qualidade dos embriões somáticos, do que os embriões em meio $\mathrm{SH}$ com razão de 9,5:1, e o melhor tempo de indução foi de 4 semanas. Cortes histológicos foram realizados para observação das caracteristicas dos embriões somáticos formados. O tratamento de maturação dos embriōes somáticos favoreceu a conversão dos embriões em plântulas, porém, em baixo percentual. Frequentemente foram observadas, tanto em meio de indução, como de maturação, uma alteração de desenvolvimento dos embriōes somáticos, com um crescimento preferencial do ápice radicular, e ausência de desenvolvimento do ápice caulinar. Em explantes de inflorescências masculinas, identificaram-se através de análises morfo-anatômicas, dois tipos de embriões somáticos: um tipo semelhante ao embrião zigótico de Musa acuminata e, em menor frequência, desenvolveram-se embriões somáticos semelhantes a embriões zigóticos de outras monocotiledôneas, indicando que em um único protocolo de embriogênese somática, é possivel ocorrer a formação de diferentes padrões morfológicos de embriões somáticos. 


\title{
BANANA (Musa spp) SOMATIC EMBRYOGENESIS: INDUCTION, MATURATION AND MORFO-ANATOMIC ANALYSIS
}

\author{
Author: SILVIA BALBÃO FILIPPI \\ Adviser: Dr. ADRIANA PINHEIRO MARTINELLI RODRIGUEZ
}

\section{SUMMARY}

The present work aimed to obtain somatic embryogenesis in Brazilian cultivars of banana and their subsequent conversion into plants. These studies are important for the development of protocols involving genetic manipulation techniques for crop improvement of this species. Initially, the induction of somatic embryogenesis from shoot apices was tested using MS medium (Murashige \& Skoog, 1962) supplemented with different auxins (dicamba, picloram, 2,4-D and NAA); three culture media with different ratios of nitric:amoniacal nitrogen $\left(\mathrm{NO}_{3}{ }^{-}: \mathrm{NH}_{4}{ }^{+}\right)$; and length of time in the induction medium. Induction was obtained but the somatic embryos did not convert into plants. Maturation treatments with higher sucrose levels or PEG (polyethylene glicol) were then tested. In addition, the use of male inflorescences were used as explants for somatic embryo induction. During the experiments, morphoanatomic analyses were performed through light and scanning electron microscopy. When shoot apices were used as explants, the auxins dicamba and picloram showed the formation of embryogenic structures and somatic embryos, 
while 2,4-D and NAA were not. Explants in medium containing dicamba presented both embryogenic regions with pro-embryos and non-organized meristematic regions, which may have formed unipolar structures. The somatic embryos were morphologically similar to the zygotic embryos of Musa acuminata, however lacked the differentiation of protoderm, meristematic apices and procambium. These somatic embryos did not convert into plants. Among the three different culture media tested for induction (SH, FN-Lite or $1 / 2 \mathrm{MS}$ ), FNLite and $1 / 2$ MS provided better quality embryos and four weeks was considered the best period for induction. These two media have a $4: 1$ and $2: 1 \mathrm{NO}_{3}{ }^{-}: \mathrm{NH}_{4}{ }^{+}$ ratio, while $\mathrm{SH}$ has a 9,5:1 ratio. Histological sections were done to evaluate the somatic embryos formed. Somatic embryo maturation treatments favored the conversion of embryos into plants, however at low frequency. Frequently, somatic embryos showed the development of the root pole only. This behavior was observed both during induction and maturation. Male inflorescence explants formed two types of somatic embryos: one morphologically resembling the zygotic embryo of Musa acuminata, and less frequently somatic embryos with morphological characteristics of other monocots. This behavior indicates that in one protocol of somatic embryogenesis it is possible to obtain different morphological patterns of somatic embryos. 


\section{INTRODUÇÃO}

A bananeira é uma das principais frutiferas do mundo, tendo posição de destaque no Brasil, pela grande importância econômica que exerce no pais. As cultivares triplóides e tetraplóides, que constituem as espécies de grande importância comercial, surgiram através da seleção natural e da domesticação pelo homem, a partir das espécies selvagens Musa acuminata e Musa balbisiana, porém, apresentam restrições ao melhoramento convencional pela baixa fertilidade de suas cultivares comerciais, produzindo frutos partenocárpicos sem sementes, ou com sementes estéries, alta poliploidia e pequena variabilidade genética.

A embriogênese somática em bananeira pode ser de grande importância como um alternativa ao melhoramento convencional, contribuindo para a obtenção de plantas transformadas, que apresentem características desejáveis, como resistência a doenças, entre outras. Contudo, para a aplicação dessas técnicas é necessário que se disponha de um sistema de cultivo in vitro para obtenção de embriões somáticos e conversão destes em plantas, para que este sistema possa ser utilizado para a manipulação genética seguida de seleção e regeneração de plantas transformadas.

Considerando-se a importância da bananeira no Brasil e no mundo, e os problemas fitossanitários que afetam esta cultura, alternativas para a obtenção de cultivares que apresentem maior resistência às doenças e pragas devem ser estudadas. A embriogênese somática, associada a técnicas de manipulação 
genética, pode contribuir para a obtenção de cultivares com características superiores.

Diversos trabalhos são apresentados na literatura, tratando da embriogênese somática de Musa spp, porém, em muitos casos, um número reduzido de embriões somáticos completam o processo de germinação. Vários fatores, como o tempo de permanência do explante no meio de indução e os meios de cultura utilizados para a indução e maturação dos embriões somáticos, influenciam as diferentes etapas de desenvolvimento do embrião somático e, consequentemente, sua germinação.

Durante o estabelecimento de sistemas de regeneração in vitro, o uso de análises morfológicas e histológicas pode auxiliar na interpretação dos problemas encontrados, indicando possiveis falhas no processo, bem como confirmar a via de regeneração, seja organogênese ou embriogênese somática.

Visando contribuir para o estabelecimento de um protocolo eficiente da embriogênese somática em bananeira, este trabalho tem como principal objetivo a obtenção de embriogênese somática em cultivares brasileiras de bananeira e subsequente conversão dos embriões em plantas. A avaliação das culturas, utilizando-se técnicas de microscopia ótica e eletrônica, pretende auxiliar a interpretação dos resultados. trazendo subsídios para a definição das etapas limitantes do processo. 


\section{REVISÃO DE LITERATURA}

\subsection{Cultura da Bananeira (Musa spp)}

A bananeira (Musa spp) é uma das principais frutíferas no mundo, constituindo importante fonte nutricional para alimentação humana, pelo alto teor calórico, valor mineral e vitamínico. As bananas são ricas em carbroidatos (25\%), fibras e $K(3,73 \mathrm{mg} / \mathrm{g})$, possuindo ainda teores consideráveis de $\mathrm{P}, \mathrm{Ca}$, $\mathrm{Fe}, \mathrm{Cu}, \mathrm{Zn}, \mathrm{I}, \mathrm{Mn}$ e $\mathrm{Co}$, além de vitamina $\mathrm{A}$, tiamina, ribloflavina, niacina, vitamina $C$. Apesar de possuir teores modestos de proteínas $(1,1 \%)$, ainda supera outras frutas como maçã, pêra ou pêssego. É amplamente consumida pela população mundial, sendo importante na dieta alimentar de crianças e atletas, pelo alto conteúdo de potássio, podendo ser consumida in natura, ou industrializada na forma de banana passa, purê, bananada, geléia, etc. (Stover \& Simmonds, 1987).

A bananeira situa-se entre as principais culturas produzidas nos paises tropicais e subtropicais, tendo expressiva comercialização e aceitação mundial.

O mercado mundial de bananas, estima-se, movimenta cerca de US $\$ 9$ bilhões por ano, com produção anual próxima de 59 milhões de toneladas, tendo seu comércio internacional aumentado $90 \%$ do início da década de oitenta até meados da década de noventa. A economia de alguns países, revela grande dependência do comércio de bananas, como ocorre com o Equador, o qual domina o mercado mundial com $26 \%$ de participação, ao 
exportar cerca de 3,5 milhões de toneladas anuais e obter receita próxima de US $\$ 900$ milhões (FNP Consultoria \& Comércio, 1999).

Apesar do Brasil ingressar o grupo dos maiores produtores de banana, com volume anual de mais de 6 milhões de toneladas, a exportação ainda é pequena, com vendas externas da ordem de $0,4 \%$ da produção. A Argentina é o principal importador desta fruta do Brasil, movimentando cerca de 35 mil toneladas/ano, seguida pelo Uruguai o qual importa 16 mil tonelada/ano do Brasil (FNP Consultoria \& Comércio, 1999). Esse baixo volume destinado à exportação, é decorrente da precária estrutura comercial brasileira, da baixa qualidade dos frutos e também do elevado consumo interno. Por ser o Brasil o maior consumidor mundial de bananas, não há excedente exportável significativo no país, apesar da elevada produção.

A bananicultura brasileira tem algumas caracteristicas que a diferencia das demais regiões produtoras do mundo, como as diferentes condições edafoclimáticas em que ela é explorada, as variações das cultivares segundo as regiões, a forma como ela é explorada e comercializada, e ainda as exigências do consumidor (Nogueira \& Ferrari, 1994).

O cultivo comercial desta fruteira está sujeito a problemas fitossanitários como a Sigatoka Negra (Mycospharella fijiensis), Mal-do-Panamá (Fusarium oxysporum var. cubense), viroses (BBTV e CMV) e ataque de pragas, como os nematóides (Radopholus similis), dificultando a ampliação do cultivo nacional de bananeira de cultivares mais suscetíveis, uma vez que o plantio fica limitado a regiões isentas destas doenças ou pragas. Mal-do-Panamá é considerada a mais importante doença da bananeira no Brasil, tendo sido o patógeno $F$. oxysporum var. cubense observado em Piracicaba, São Paulo, em 1930, e agora, difundido para outras regiōes produtoras. A doença, normalmente, aparece em reboleiras e rapidamente espalha-se por toda a plantação, podendo, em poucos meses, destruir todas as plantas de bananeira. Plantações comerciais de cultivar Maçã (AAB), suscetível ao F. oxysporum var. 
cubense, foram praticamente eliminadas dos estados de São Paulo, Espírito Santo, do Triângulo Mineiro e do sul de Goiás, sendo necessárias novas áreas para o estabelecimento da cultura (Ploetz et al., 1993).

Pertencente à família Musaceae, os grupos de Musa spp - AA, AAA, $A B B, A B B B$ e AAAA, são resultado de seleção natural, através de hibridação das espécies selvagens Musa acuminata (AA) e Musa balbisiana (BB), ambas diplóides $(2 n=22)$. As cultivares triplóides e tetraplóides, que constituem as espécies comestiveis e, portanto, de grande importância comercial, surgiram através da seleção natural e da domesticação pelo homem. Apresentam porém, características desfavoráveis ao melhoramento convencional, como a baixa fertilidade, produzindo frutos partenocárpicos sem sementes, ou com sementes estéries, alta poliploidia e pequena variabilidade genética (May et al., 1995), dificultando a ampliação do cultivo nacional de bananeira de cultivares mais suscetiveis às doenças.

Por apresentar essas dificuldades e pela necessidade de obtenção de cultivares mais resistentes, principalmente a problemas fitossanitários, a bananeira pode-se beneficiar grandemente da associação de técnicas de cultura de tecidos e de biologia molecular com os programas tradicionais de melhoramento genético. Técnicas de transformação genética possibilitam a introdução de genes exógenos, que apresentem características desejáveis, como resistência a doenças, entre outras. Contudo, para a aplicação dessas técnicas é de grande importância que se disponha de um sistema de cultivo in vitro para obtenção de embriōes somáticos, que possam ser utilizados para a manipulação genética, seguida de seleção e regeneração de plantas transformadas. 


\subsection{Cultivo in vitro da bananeira}

\subsubsection{Micropropagação}

A multiplicação da bananeira ocorre vegetativamente pela emissão de novos rebentos, utilizados pelos agricultores para o plantio comercial. Entretanto, a facilidade de dissiminação de patógenos, a falta de qualidade das mudas, associadas ao maior custo de implantação da cultura pela pequena quantidade de mudas obtidas, levou à busca por novas tecnologias, visando a expansão da cultura da bananeira (Ruggiero et al. 1994).

As técnicas biotecnológicas, utilizadas não somente para a cultura da bananeira, oferecem novas alternativas aos programas de melhoramento em suas diferentes fases, possibilitando o desenvolvimento de novas cultivares, ou contribuindo com a multiplicação massal de plantas elite e também na conservação de germoplasma.

A propagação vegetativa in vitro, também denominada de micropropagação, devido ao tamanho dos propágulos utilizados, é uma das técnicas amplamente usadas na cultura de tecidos. Ápices meristemáticos, gemas axilares e meristemas isolados são os explantes mais indicados para a propagação massal in vitro (Grattapaglia \& Machado, 1998).

A utilização prática da técnica de micropropagação, refere-se à produção comercial de plantas, possibilitando sua multiplicação rápida e em períodos de tempo e espaço físico reduzido, com obtenção de mudas com qualidade fitossanitária (Rodrigues, 1996). No entanto, a eficiência na produção de brotos durante a micropropagação de bananeira, variam conforme o genótipo utilizado (Mendes et al. 1999). Na microprogagação de Musa spp cultivar Nanicão (grupo AAA), Mendes et al. (1996) verificaram uma grande quantidade de brotos produzidos, e um aumento na razão de multiplicação com o tempo de subcultivo. Na cultivar Maçã (grupo AAB), porém, além da pequena produção 
de brotos, houve um decréscimo na razão de multiplicação após o quarto subcultivo (Mendes et al. 1999).

A bananeira é uma das primeiras culturas a serem utilizadas na propagação in vitro em grande escala no Brasil, abrindo novas perspectivas no cenário nacional da bananicultura. No início da década de 90 , biofábricas foram criadas visando a micropropagação de cultivares comerciais de bananeira. A carência de informações e de domínio dessa nova tecnologia e a ausência de legislação para produção de mudas produzidas através da micropropagação, foram responsáveis pela colocação no mercado de um produto de qualidade duvidosa, podendo causar prejuizos aos agricultores, pela possibilidade de ocorrência de variação somaclonal provenientes do cultivo in vitro inadequado (Rodrigues, 1996). Esperava-se uniformidade genética no material micropropagado já que a técnica de micropropagação, envolve basicamente divisões mitóticas. Porém a variação somaclonal observada em cultura de tecidos é decorrente, entre outros, do meio de cultivo, com o uso de reguladores vegetais, da susceptibilidade da cultivar utilizada e número de subcultivos (Skirvin et al., 1994).

Rodrigues (1996), estudou o efeito do número de subcultivos em meio contendo benzilaminopurina (BAP) na taxa de variação somaclonal nas cvs. Nanicão e Grand Nain. Verificou que a variação somaclonal aumentava com o número de subcultivos, identificando um máximo de 6 a 7 subcultivos para obtenção de mudas com elevada uniformidade e baixa taxa de variação somaclonal.

Atualmente, tem-se dado preferência às mudas de bananeira provenientes de micropropagação para a utilização no estabelecimento ou renovação de plantações, melhorando a relação custo/benefício para o produtor.

As plântulas de bananeira micropropagadas também podem contribuir para o melhoramento vegetal, servindo como fonte de explantes em protocolos 
de regeneração in vitro, como a embriogênese somática, além de sua importância na multiplicaçăo de clones elite.

\subsubsection{Embriogênese somática em Musa spp}

Vários estudos visando a embriogênese somática e regeneração em plantas foram realizados em Musa spp, utilizando como explantes embriões zigóticos imaturos (Escalant \& Teisson, 1987; Marroquin et al., 1993; Navarro et al., 1997), ápices vegetativos (Novak et al., 1989; Lemos, 1994; Lee et al., 1997) ou inflorescências (Srinivasa Rao \& Chacko, 1982; Escalant et at., 1994; Côte et al., 1996; Navarro et al., 1997).

Alguns protocolos que apresentam alta regeneração de plantas obtém embriões somáticos a partir de embrião zigótico (Marroquin et al., 1993; Navarro et al., 1997), mas a natureza do explante limita o método a espécies selvagens, uma vez que as cultivares comerciais não produzem sementes. $O$ uso de inflorescências de cultivares comerciais de Musa spp parece promissor (Escalant et al., 1994; Côte et al., 1996).

Escalant et al. (1994), obtiveram embriões somáticos e posterior regeneração de plantas de cultivares comerciais de Musa spp, utilizando como explantes inflorescências jovens masculinas, cultivadas em meio MS (Murashige \& Skoog, 1962) suplementado com $1 \mathrm{mg} / \mathrm{IAA}$ (ácido indolacético), 4 mg/l 2,4-D (ácido 2,4-diclorofenoxiacético) e 1 mg/l NAA (ácido naftalenoacético), para indução de embriogênese somática. Após 1 a 2 meses da indução, os explantes formavam calos amarelados e pequenos, sendo que após 3 a 5 meses, surgiam na superfície destes, calos brancos e translúcidos, a partir dos quais desenvolviam-se embriōes somáticos. Estes embriōes eram transferidos para meio de germinação com reduzida concentração de auxina (0,2 mg/l IAA) e citocinina (0,05 mg/l BAP), obtendo-se um elevado índice de germinação $(80 \%)$. As respostas foram diferenciadas entre as cultivares 
estudadas e o periodo testado. Os autores testaram também o sistema de imersão temporária, obtendo grande proliferação de embriões somáticos, sendo esta técnica considerada eficiente na propagação massal in vitro.

Côte et al. (1996), iniciaram culturas de células em suspensão, a partir de tecidos embriogênicos oriundos de inflorescências masculinas de Musa spp cv. Grand Nain, as quais produziram, após 5 a 6 meses em meio de indução, grande quantidade de calos compactos, amarelados ou brancos e friáveis, obtendo, posteriormente, grande quantidade de embriões. Entre 3 a $20 \%$ dos embriões formados foram convertidos em plantas.

Anteriormente, Srinivasa Rao \& Chacko (1982) utilizando inflorescências jovens de Musa acuminata L. Robusta em meio contendo 2,4,5-T (ácido 2,4,5triclorofenoxiacético), descreveram o desenvolvimento de calos seguido de estruturas proembriogênicas, observando em sequência somente a formação de raízes. Os protocolos de Escalant et al. (1994) e Côte et al. (1996) apresentaram avanço considerável, utilizando cultivares comerciais e com boa taxa de conversão (Escalant et al., 1994).

A utilização de ápice vegetativo como explante em protocolos de embriogênese somática de Musa spp, também trouxe alguns resultados satisfatórios. Novak et al. (1989), utilizando ápices vegetativos de plântulas de Musa spp, em meio de indução com sais SH (Schenk \& Hildebrandt, 1972) e com dicamba, obtiveram, a partir de cultura em suspensão, diferentes respostas de proliferação. Estas respostas embriogênicas, estavam associadas ao genótipo usado. Nas culturas da cultivar triplóide Cardaba (ABB) observaram-se somente protuberâncias globulares, sem formação de calos, enquanto que nos clones diploides (AA) 'SH-3362' e 'Bocadillo' proliferaram calos e estruturas proembriônicas. Na cultivar triplóide Grand Nain (AAA) formaram-se calos semi-compactos com pouca formação proembriônica. Os autores obtiveram, nas quatro cultivares de Musa, regeneração em plantas, porém, em baixa porcentagem (1,5\%). 
No Brasil, Lemos (1994) trabalhou com as cultivares Grand Nain (AAA), Mysore e Prata (ambas $A A B$ ), realizando diversos testes de cultura de ápices vegetativos, e utilizando diferentes concentrações de dicamba e 2,4-D para a indução de embriogênese somática. Verificou-se que dicamba na concentração de $10 \mu \mathrm{M}$ respondeu melhor à formação de estruturas globulares, independente da cultivar utilizada. Apenas um pequeno número de estruturas globulares individuais originaram plântulas com desenvolvimento inicial de parte aérea e posteriormente, raízes, demonstrando a dificuldade de conversão em plantas.

Vários autores descreveram a formação de massas de calos esféricos, em cultura de tecidos de Musa spp assemelhando-se a embriōes somáticos, porém sem a ocorrência posterior de diferenciação de parte aérea (Cronauer \& Krikorian, 1983; Banerjee et al., 1987; Lee et al., 1997).

Pela observação dos trabalhos citados, pode-se sugerir que a embriogênese somática em cultivares comerciais de bananeira ainda demanda maiores estudos, fazendo-se alterações nas condições de cultivo. Embriões somáticos foram obtidos por vários autores, porém, observaram-se muitas diferenças entre os protocolos, variando-se as cultivares, o tipo de explante, e as condições de cultivo. Na maioria dos trabalhos, a taxa de conversão em plantas é baixa.

\subsection{Fatores que afetam a embriogênese somática}

A indução de embriogênese somática está relacionada a alterações no padrão de expressão gênica nos explantes, com reprogramação das células que estarão envolvidas no processo embriogênico (Merkle et al., 1995). Na fase

em que as estruturas embriogênicas se formam, poderá, ou não, ocorrer a diferenciação em embriões somáticos, de acordo com as próprias características morfológicas, anatômicas e funcionais das estruturas formadas. 
Diversos fatores estão relacionados à indução do estágio embriogênico. Merkle et al. (1995) citam, entre outros, o genótipo/espécie, características dos explantes, tipo e regime de aplicação de reguladores vegetais, outros componentes do meio, como cálcio, fonte de nitrogênio, açúcar, e condições ambientais.

Em cultura de tecidos, é importante a alteração do meio de cultivo, de acordo com a fase da morfogênese e da exigência da cultura. No caso da soja (Glicine max), o meio MS é usado para indução e conversão de embriões somáticos, enquanto que o meio $\mathrm{FN}$ é usado para proliferação da cultura embriogênica (Samoylov et al., 1998). Sabe-se que o meio SH foi otimizado para crescimento de calos em monocotiledôneas (Schenk \& Hildebrandt, 1972), o meio FN foi desenvolvido para iniciação de cultura em suspensão de soja (Finer \& Nagasawa, 1988), enquanto que o meio MS foi inicialmente testado para o crescimento de calos em tabaco (Nicotiniana spp) (Murashige \& Skoog, 1962). $\mathrm{O}$ meio MS é muito utilizado em cultivo in vitro de plantas, diferenciando-se de outros meios de cultura, principalmente pela elevada concentração de nitrogênio na forma de amônio e maiores concentrações de fósforo e potássio.

Alterações na composição dos meio de cultura, conforme o material vegetal e a resposta morfológica esperada, podem contribuir para a otimização dos processos morfológicos.

Um fator de importância refere-se ao nitrogênio suplementado durante o processo embriogênico, nutriente indispensável para formação de proteínas, ácido nucleicos e síntese de substâncias de reserva (Merkle et al. (1995). Em sementes, o embrião imaturo não possui a enzima ativa redutase nitrato, que reduz nitrato $\left(\mathrm{NO}_{3}{ }^{-}\right)$a nitrito, e depois a amônio $\left(\mathrm{NH}_{4}{ }^{+}\right)$, sendo então de grande importância a utilização de nitrogênio reduzido no cultivo do embrião somático (Monnier, 1995).

Em condições in vitro, o amônio parece ser indispensável para a iniciação da embriogênese somática, porém, o nitrogênio na forma de nitrato 
pode ser suficiente para o desenvolvimento dos embriões, os quais podem adquirir nitrogênio reduzido, frequentemente liberado por células vivas e mortas em cultivo (Nomura \& Komamine, 1995). A relação nitrato:amônio e a quantidade total de nitrogênio, porém, parece variar conforme as condições de cultivo e espécie.

Walker \& Sato (1981), estudando o papel do ín amônio na morfogênese in vitro de alfafa (Medicago sativa), observaram que a embriogênese não ocorria na ausência de nitrato ou amônio, sendo que na ausência ou à baixa concentração de $\mathrm{NH}_{4}^{+}(2,5 \mathrm{mM})$, ocorria somente rizogênese, sendo esta inibida em alto nível de amônio $(50 \mathrm{mM})$. Estes autores observaram que niveis intermediários de íon amônio no meio de regeneração, resultaram tanto na formação de raíz, como de embriões somáticos, sugerindo que o processo morfogênico de indução de embriogênese somática em alfafa resulta da interação entre reguladores vegetais e amônio.

A presença de nitrogênio reduzido na forma de ion amônio ou aminoácidos, estimula a embriogênese em algumas espécies, porém, alta concentração de ion amônio pode inibir a indução de embriogênese somática (Trigiano et al., 1988). Trigiano et al. (1988), utilizando como explantes embriões imaturos de Cercis canadensis, em meio de cultura $\mathrm{SH}$ modificado, com 12,6 mM de $\mathrm{NH}_{4}^{+}$, observaram que este nivel de amônio inibia a formação de embrões somáticos. Meijer \& Brown (1987), também demonstraram que alta concentração de $\mathrm{NH}_{4}^{+}$inibia embriogênese somática em Medicago sativa, enquanto que $5 \mathrm{mM}$ de amônio induzia a formação de embriōes somáticos. Samoylov et al. (1998), alterando a razão de nitrato:amônio no meio de cultura em cotilédones imaturos de soja, usando amônio como única fonte de nitrogênio (razão 0:1), observaram que embriões cresciam desordenadamente e a cultura passava à coloração amarela-marrom. Quando usaram somente nitrato, observou-se a formação de grupos embriogênicos com embriões 
pequenos, de coloração amarelada. Estes autores verificaram que a melhor razão nitrato:amônio, na embriogênese somática em soja, foi de 4:1.

O efeito das auxinas não pode ser considerado independente dessa redução de nitrogênio, havendo interação entre esses dois componentes do meio de cultura (Mohan Ram et al., ${ }^{1} 1982$, citado por Merkle et al., 1995).

Apesar de não ser totalmente conhecido o modo de ação das auxinas no processo embriogênico, estas são, provavelmente, um dos produtos mais utilizados para a indução de embriogênese somática em diversas espécies (Merkle et al., 1995). As auxinas 2,4-D e dicamba são as mais utilizadas para promover a formação de células embriogênicas em cultivares de Musa spp, sendo que com picloram há poucos trabalhos desenvolvidos (Escalant \& Teisson, 1989; Marroquin et al., 1993). Esses autores foram os primeiros a relatar a eficiência de picloram para a indução de embriogênese somática e de suspensão embriogênica, respectivamente, obtendo calos embriogênicos a partir de embriōes zigóticos de Musa acuminata e Musa balbisiana.

A exposição à auxina é essencial para a indução do estágio embriogênico, mas a sua continuação torna-se prejudicial ao processo de histodiferenciação. O papel da auxina durante a fase de histodiferenciação, bem como altas concentrações de auxina no meio de indução, podem interferir no desenvolvimento do embrião somático. Halperin e Wetherell (1964) foram os primeiros a observar que a manutenção de 2,4-D nos embriōes somáticos de cenoura no estágio globular, inibiu a histodiferenciação ou conduziu ao desenvolvimento anormal do meristema apical. Observação similar demonstrou que o tempo de exposição à auxina, foi inversamente proporcional ao desenvolvimento de embriões somáticos em soja (Glicine max) (Parrott et al., 1988). Stuart et al., (1988), notaram a importância da remoção do regulador de

\footnotetext{
${ }^{1}$ MOHAN RAM, H.Y.; MEHTA, U.; RAMANUJA RAO, I.V.; NARASIMHAM, M. Haploid induction in legumes. In: FUJIWARA, A. (Ed.) Plant Tissue Culture. Tokyo:Japanese Association for Plant Tissue Culture, 1982. p.541.
} 
crescimento no meio de indução, para a expressão de proteínas de reserva. Nesse estudo, embriões somáticos de alfafa induzidos em meio contendo $50 \mu$ M 2,4-D exibiam baixo acúmulo de proteínas de reserva, enquanto que aqueles induzidos em $10 \mu \mathrm{M}$ 2,4-D apresentaram alto nivel de proteínas de reserva. Segundo os autores, esses resultados sugerem que o elevado nível de auxina durante a indução levou ao acúmulo desta substância, podendo ter ocorrido a supressão da expressão de genes relacionados à síntese de proteínas de reserva $e$, consequentemente, o seu acúmulo. Além disso, a presença de auxina exógena pode conduzir ao desenvolvimento anormal, ou supressão do eixo embrionário (Merkle et al., 1995 ).

O processo de conversão do embrião somático em plantas, com o desenvolvimento simultâneo do ápice radicular e meristema caulinar é pouco eficiente em Musa spp (Novak et al., 1989; Lee et al., 1997). As caracteristicas morfológicas do embrião somático podem afetar a germinação e, consequentemente, a conversão dos embriões somáticos em plantas (Rodriguez \& Wetzstein, 1994).

Estudos recentes indicam que a maturação adequada do embrião somático permite uma melhor germinação do embrião, aumentando a eficiência da conversão e regeneração de plântulas. Após a divisão celular e histodiferenciação, o periodo do desenvolvimento do embrião em que ocorre expansão das células, desidratação e acúmulo substâncias de reservas é considerada a fase de maturação (Bewley \& Black, 1985).

O meio de cultura durante a maturação é algo crítico. Protocolos desenvolvidos por Slawinska e Obendorf (1991), foram eficientes no processo de maturação de embriões somáticos de soja, permitindo um estágio quiescente sem ocorrer a germinação precoce. A germinação precoce é caracterizada por uma elongação prematura de células do hipocótilo e do ápice caulinar, durante a elongação da radícula (Monnier, 1995). Se a germinação precoce for inibida e o processo de maturação prolongado, pode-se obter um 
sincronismo no desenvolvimento do embrião somático, revertendo em um maior percentual de conversão em plântulas normais.

Vários trabalhos (Roberts et al., 1990; Misra et al., 1993; Capuana \& Debergh, 1997; Li et al., 1998) têm documentado o uso de ácido abscísico $(A B A)$, polietilenoglicol (PEG) e sacarose na dessecação de embriões somáticos e na prevenção da germinação precoce, principalmente em espécies florestais, mas o uso de agentes de maturação em Musa spp, ainda não foi relatado.

Attree et al. (1991), em experimento com coniferas, observaram que o efeito de estresse hidrico provocado por PEG, quando associado ao ABA no meio de maturação, produziu embriões somáticos semelhantes ao embrião zigótico em termos de umidade (conteúdo de água), alto grau de quiescência e habilidade de sobreviver à dessecação. A dessecação e subsequente reidratação, pode benificar a conversão em algumas espécies.

Li et al. (1998), estudando o efeito da maturação em embriões somáticos de Pinus taeda L., observaram um efeito superior de polietilenoglicol (PEG) em relação à maltose. Segundo Attre \& Fowke (1993), PEG com peso molecular acima de 3000 , não provoca plasmólise nas células, apesar do potencial osmótico elevado.

Misra et al. (1993) através de tratamento com PEG em combinação com ABA, em embriões somáticos de Picea glauca (Moench) Voss obtiveram uma gama de polipeptídeos semelhantes aos encontrados nos embriões zigóticos maduros. No entanto, na maturação do embrião somático em meio contendo $A B A$ e baixo potencial osmótico, mostrou ausência de algumas formaçōes de cristalóides e matrizes polipeptídicas. Capuana \& Debergh (1997), obtiveram resultados semelhantes, mostrando que a melhor atividade de maturação, foi obtida a partir de meio enriquecido com ABA e PEG.

$\mathrm{Xu}$ et al. (1990) indicaram que o estresse osmótico pode prevenir a germinação precoce no desenvolvimento do embrião zigótico de alfafa 
(Medicago sativa L.). Elevado potencial osmótico é também requerido para o desenvolvimento de embrióides a partir de pólen de canola (Dunwell \& Thurling, 1985) e na maturação de embrião somático de soja (Buchheim et al., 1989; Slawinska \& Obendorf, 1991).

Após o desenvolvimento do embrião zigótico, ocorre um período de dormência quando ocorre também a desidratação. Durante este período de maturação, ocorrem acúmulo de reservas e o endurecimento dos integumentos, formando-se assim a semente (Monnier, 1995). O acúmulo de reservas é necessário para a germinação e o desenvolvimento do embrião em nivel autotrófico (Merkle et al., 1995). Yeung (1995) comenta sobre as similaridades entre a embriogênese zigótica e somática. Segundo este autor, apesar de haver diferenças entre os dois sistemas, a partir da fase globular as estratégias de desenvolvimento são muito semelhantes. Um estudo da sequência de desenvolvimento do embrião zigótico pode ser utilizada para otimização do sitema de embriogênese somática.

Recentemente, os estudos sobre acúmulo de proteínas e sua síntese, abriram um expressivo caminho para a questão do metabolismo de proteínas e o desenvolvimento do embrião. O final da fase de proliferação e crescimento do embrião marca o início da síntese e acumulação de proteína, conduzindo ao incremento do vigor e peso seco do embriāo (Monnier, 1995).

As análises de acúmulo de reservas no desenvolvimento dos embriōes somáticos podem revelar semelhanças ou diferenças notáveis, quando comparadas a embriōes zigóticos. Estas diferenças e os casos anormais de expressão de proteínas de reserva em embriões somáticos, podem, ser atribuídas às condições de cultivo usadas durante a maturação in vitro. A manipulação das condições do meio de cultivo para prolongar a maturação do embrião e prevenir a germinação precoce, podem favorecer a similaridade entre embriōes zigóticos e somáticos (Merkle et al., 1995). 
Nos trabalhos de embriogênese somática de Musa spp, apesar de baixa conversão de embriões em plantas em vários protocolos, não há relatos de experimentos visando a maturação dos embriões somáticos.

\subsection{Histologia e Morfologia}

No processo de regeneração in vitro, o uso de análises histológicas e morfológicas do material vegetal, utilizando técnicas de microscopia ótica e eletrônica, pode ser fundamental para interpretação do mesmo.

As análises histológicas, podem ser utilizadas para caracterizar as alterações celulares, identificar e caracterizar a formação de estruturas monopolares ou bipolares, analisando-se a qualidade e o desenvolvimento destas estruturas. Juntamente com análises morfológicas do material vegetal, pode-se caracterizar a via de regeneração, permitindo compreender melhor a morfogênese in vitro, visando a otimização dos protocolos de obtenção de plântulas em cultura de tecidos.

O caminho de regeneração in vitro consiste, basicamente, de três fases: desdiferenciação, onde o tecido adquire competência para responder ao processo morfogênico; indução, quando as células tornam-se determinadas a desenvolver estrutura monopolar (ápice radicular ou ápice caulinar) ou bipolar (embrião), e desenvolvimento, com crescimento de órgãos ou embrião (De Klerk et al. 1997).

$\mathrm{Na}$ fase de indução, as análises histológicas permitem caracterizar as alterações celulares. As células morfogênicas caracterizam-se por serem pequenas, com citoplasma denso, nucléolo grande, pouca vacuolização e pequenos grânulos de amido (Michaux-Ferrière \& Schwendiman, 1992). O desenvolvimento destas células não é sincronizado, variando conforme as condições do meio de cultura, sendo capazes de se dividirem ou se envolverem 
na formação de embriões. As células que não formam pró-embriões, começam o processo de diferenciação, ou seja, a vacuolização, diminuição em volume do nucléolo e o acúmulo ou o desaparecimento de grânulos de amido (MichauxFerrière \& Schwendiman, 1992).

A adequação do meio de cultura, torna-se essencial para a expressão do potencial embriogênico destas células. Os embriões somáticos podem iniciar-se em diferentes tempos durante o desenvolvimento dos calos, variando de poucas semanas a vários meses no meio de cultura (Michaux-Ferrière \& Schwendiman, 1992). Michaux-Ferrière \& Carron (1989), através de análises histológicas, estudaram o efeito da permanência do calo no meio de cultura e o seu tempo de subcultivo em Hevea brasiliensis. Observaram que cerca de 20 a $60 \%$ dos calos, convergiam em embriōes, sendo que destes, poucos eram totalmente formados. Os embriões apresentavam ausência de individualização do meristema caulinar, devido ao desenvolvimento desigual dos cotilédones e a ocorrência de embriões fusionados.

Através de análises histológicas, Goh et al. (1999) observaram que células vasculares de raizes de Calamus manan, cultivadas em meio com 7,5 $\mathrm{mg} / \mathrm{l}$ picloram, originaram calos embriogênicos, com características de células morfogências, com núcleo grande, grande divisão celular e alta razão núcleo/citoplasma.

Em várias culturas, verifica-se que um grande número de células embriogênicas são iniciadas durante o processo de embriogênese somática, mas nem todas têm habilidade de se desenvolverem em pró-embriões. Consequentemente, o número de embriões bipolares formados é relativamente menor quando comparados ao número de pró-embriões globulares ou de células embriogênicas. Essa baixa capacidade de conversão do embrião somático em plântula, não se restringe apenas às inadequadas condições do meio de cultura, mas refere-se à ontogênese anormal ou imatura do embrião 
somático, quando comparado com o embrião zigótico (Michaux-Ferrière \& Schwendiman, 1992).

Assim as análises histológicas e morfológicas, também podem contribuir para estudos da ontogênese dos embriões somáticos, identificando as possíveis falhas no seu desenvolvimento, além da comparação com embriões zigóticos.

Diversas anormalidades de embriões somáticos - como falha estrutural ou funcional do meristema caulinar (Nickle \& Yeung, 1993), prematura conversão/germinação do embrião (Ammirato, 1985), cotilédones aberrantes (Fujji et al., 1990), desintegração do meristema caulinar (Yeung et al., 1996), foram encontradas em protocolos de embriogênese somática.

Alemanno et al. (1997), observaram $80 \%$ de anormalidade nos embriōes somáticos de Theobroma cacao. Nas análises histológicas, observaram embriões somáticos pobres em amido e proteínas de reserva, além de apresentarem alto conteúdo de água em comparação com os embriões zigóticos.

Padmanabhan et al. (1998), através de análises histológicas e morfológicas identificaram 5 tipos de variantes no embrião somático de Ipomoea batatas, sendo que a formação do meristema caulinar foi menos frequente do que a formação de meristema radicular, conduzindo à baixa conversão em plântula. Segundo os autores, as anormalidades observadas, foram associadas principalmente com a falta de organização do meristema apical caulinar.

As análises histológicas e morfológicas de protocolos de embriogênese somática em cultivares de Musa spp, revelaram alguns aspectos dos embriões somáticos como; melhor formação do ápice radicular, porém deficiente formação do ápice caulinar (Cronauer \& Krikorian, 1983; Banerjjee et al., 1987; Lee et al., 1997), embriões somáticos normais com desenvolvimento bipolar (ápice caulinar e radicular) (Marroquin et al., 1993; Escalant et al., 1994; Côte 
et al., 1996), várias estágios de desenvolvimento dos embriōes somáticos (Escalant et al., 1994; Lee et al., 1997; Navarro et al., 1997), ou comparando-os com embrião zigótico de Musa balbisiana (Escalant \& Teisson, 1987).

Estas análises de microscopia ótica e eletrônica do material vegetal in vitro de Musa spp ou de outras espécies torna-se necessária, pois permite detectar possiveis anormalidades no processo, bem como confirmar a via de regeneração, seja organogênese ou embriogênese somática. 


\section{MATERIAL E MÉTODOS}

Os experimentos foram realizados no Laboratório de Biotecnologia Vegetal do Centro de Energia Nuclear na Agricultura, USP. Material vegetal para os experimentos foi obtido junto a produtores de banana, ou no pomar do Departamento de Produção Vegetal da ESALQ, USP. Para a indução de embriogênese somática foram utilizados dois tipos de explantes: segmento longitudinal de ápice vegetativo de plântulas micropropagadas e inflorescência funcionalmente masculina. Para a obtenção dos explantes de ápice vegetativo, portanto, inicialmente foi necessária a introdução de material in vitro para micropropagação.

\subsection{Micropropagação}

Foram coletadas no campo, mudas de rizoma tipo "chifre" de plantas das cultivares Nanicão (grupo AAA) e Ouro (grupo AA) (Fig. 1a). O excesso de tecido do rizoma e as folhas mais externas foram retiradas, obtendo-se um material com aproximadamente $10 \mathrm{~cm}$ de altura e $3 \mathrm{~cm}$ de diâmetro, composto de parte do tecido do rizoma e o meristema apical envolto por várias bainhas foliares. No laboratório, o material foi submetido a desinfecção com hipoclorito de sódio, na proporção $2: 1$, durante 30 minutos.

Após a assepsia, lavou-se o material com água destilada e autoclavada

por 3 vezes no interior da câmara de fluxo laminar. Em seguida, procedeu-se ao preparo do ápice vegetativo, constituído de vários primórdios foliares 
envolvendo o meristema apical caulinar, e parte do tecido do rizoma. Os ápices vegetativos foram introduzidos em frascos de vidro, com $30 \mathrm{ml}$ de meio de cultura constituido de vitaminas e sais de MS (Murashige \& Skoog, 1962) (Tabs. 1 e 2), suplementado com $12 \mu \mathrm{M}$ BAP, $100 \mathrm{mg} / \mathrm{L}$ inositol, $30 \mathrm{~g} / \mathrm{L}$ sacarose e $2 \mathrm{~g} / \mathrm{L}$. Phytagel, e mantidos sob fotoperiodo de 16 horas $(40 \mu \mathrm{mol} . \mathrm{m}$ $\left.{ }^{2} \cdot \mathrm{s}^{-1}\right)$, à temperatura de $27 \pm 2^{\circ} \mathrm{C}$. Após 4 semanas, os explantes foram transferidos, individualizando-se as brotações e transferindo-as para recipientes tipo "magenta", contendo $50 \mathrm{ml}$ de meio novo, agora com BAP na concentração de $20 \mu \mathrm{M}$. O subcultivo foi realizado em intervalos de 4 semanas, até o sexto subcultivo. Em cada subcultivo, colocavam-se 4 ou 5 brotos por magenta. Após o sexto subcultivo, as brotações obtidas foram transferidas para vidros de 250 $\mathrm{ml}$, contendo mesmo meio de cultura $(50 \mathrm{ml})$, mas sem regulador vegetal. As brotações permaneceram por 6 a 8 semanas, para adquirirem espessura na base, enraizarem e serem utilizadas como fonte de explantes para o processo de embriogênese somática.

Tabela 1. Composição da solução de vitaminas de Murashige \& Skoog (1962).

\begin{tabular}{lc}
\hline Vitaminas & $(\mathbf{m g} / \mathbf{L})$ \\
\hline Thiamina-HCl & 0,1 \\
Piridoxina-HCl & 0,5 \\
Ácido nicotinico & 0,5 \\
Glicina & 2,0 \\
\hline
\end{tabular}


Tabela 2. Teores de sais minerais entre três meios de cultura

\begin{tabular}{|c|c|c|c|}
\hline \multirow[t]{2}{*}{ Macronutrientes } & \multicolumn{3}{|c|}{ Meio de cultura * } \\
\hline & MS (mg/L) & FN-Lite (mg/L) & $\mathrm{SH}(\mathrm{mg} / \mathrm{L})$ \\
\hline $\mathrm{KNO}_{3}$ & 1.900 & 2.830 & 2.500 \\
\hline $\mathrm{NH}_{4} \mathrm{NO}_{3}$ & 1.650 & $-\cdots$ & $-\cdots$ \\
\hline$\left(\mathrm{NH}_{4}\right)_{2} \cdot \mathrm{SO}_{4}$ & ---- & 463 & ---- \\
\hline $\mathrm{MgSO}_{4} \cdot 7 \mathrm{H}_{2} \mathrm{O}$ & 370 & 370 & 400 \\
\hline $\mathrm{CaCl}_{2} \cdot 2 \mathrm{H}_{2} \mathrm{O}$ & 440 & 440 & 200 \\
\hline $\mathrm{KH}_{2} \mathrm{PO}_{4}$ & 170 & 185 & -- \\
\hline $\mathrm{NH}_{4} \mathrm{H}_{2} \mathrm{PO}_{4}$ & $-\cdots$ & ---- & 300 \\
\hline Micronutrientes & (mg/L) & (mg/L) & $(\mathrm{mg} / \mathrm{L})$ \\
\hline $\mathrm{MnSO}_{4} \cdot \mathrm{H}_{2} \mathrm{O}$ & 22,3 & 22,3 & 10,0 \\
\hline $\mathrm{KI}$ & 0,83 & 0,83 & 1,0 \\
\hline $\mathrm{H}_{3} \mathrm{BO}_{3}$ & 6,2 & 6,2 & 5,0 \\
\hline $\mathrm{ZnSO}_{4} \cdot 7 \mathrm{H}_{2} \mathrm{O}$ & 8,6 & 8,6 & 1,0 \\
\hline $\mathrm{CuSO}_{4} \cdot 5 \mathrm{H}_{2} \mathrm{O}$ & 0,025 & 0,025 & 0,2 \\
\hline $\mathrm{Na}_{2} \mathrm{MoO}_{4} \cdot 2 \mathrm{H}_{2} \mathrm{O}$ & 0,25 & 0,25 & 0,1 \\
\hline $\mathrm{CoCl}_{2} \cdot 6 \mathrm{H}_{2} \mathrm{O}$ & 0,025 & 0,025 & 0,1 \\
\hline $\mathrm{FeSO}_{4} \cdot 7 \mathrm{H}_{2} \mathrm{O}$ & 2.780 & 2.780 & 2.780 \\
\hline $\mathrm{Na}_{2}$ EDTA & 3.360 & 4.170 & 3.360 \\
\hline
\end{tabular}



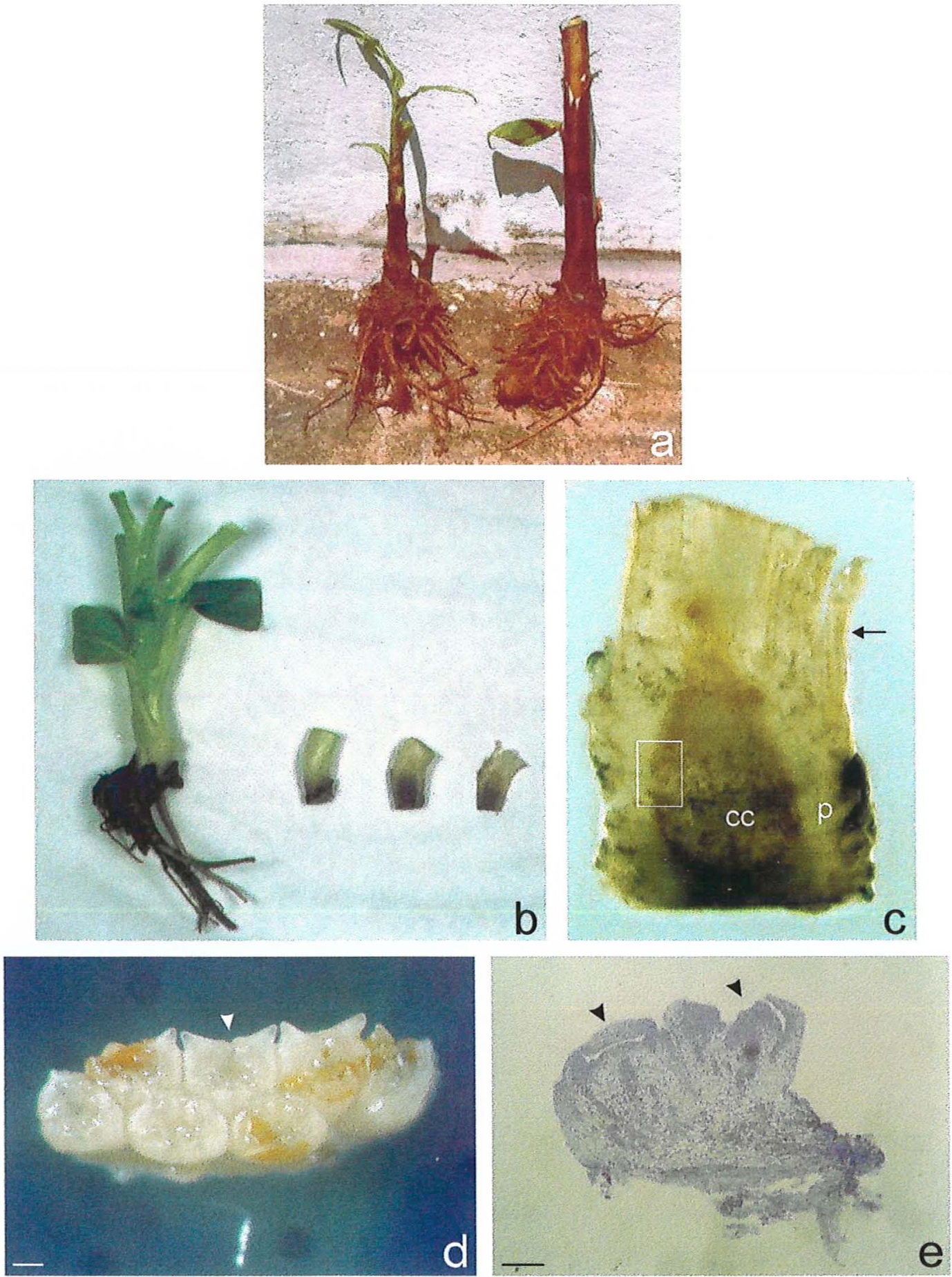

Figura 1. Material utilizado como explante para indução de embriogênese somática em bananeira. a) muda de rizoma tipo "chifre" para obtenção de ápice vegetativo para micropropagação (cv. Ouro); b) plântula multiplicada in vitro; após retirada das folhas e raízes e seccionada longitudinalmente com, aproximadamente, $1 \mathrm{~mm}$ de espessura; c) segmento longitudinal do ápice vegetativo utilizado como explante (seta $=$ base das folhas, $c c=$ cilindro central, $p=$ parênquima cortical); d) dicásio obtido da região ândrica, com sete botões florais (ponta de seta); e) seção longitudinal da inflorescência, mostrando botões florais (ponta de seta). Barras $=200 \mu \mathrm{m}$. (retângulo corresponde ao local de onde foram coletadas amostras apresentadas na fig. 2). 


\subsection{Embriogênese Somática a partir de explantes de ápice vegetativo}

a) Preparo do explante: Plântulas de bananeira (Musa spp) multiplicadas e enraizadas (ítem 3.1) e com aproximadamente $1 \mathrm{~cm}$ na base foram coletadas para a obtenção de explantes. Em câmara de fluxo laminar, com auxílio de pinça e bisturi, cortaram-se as folhas e raizes (Fig. 1b). Os explantes foram preparados seccionando-se longitudinalmente os ápices vegetativos, com tamanho aproximado de 5 a $10 \mathrm{~mm}$ de comprimento, $5 \mathrm{~mm}$ de largura e 1 a 2 $\mathrm{mm}$ de espessura, contendo parte do rizoma e primórdio foliares (Figs. 1b,c).

3.2.1. Comparação do efeito de diferentes auxinas na indução de embriogênese somática na cv. Nanicão

Seis segmentos (explantes) (Fig. 1c) foram colocados em sentido horizontal em placas de Petri de $90 \mathrm{~mm}$ contendo meio de cultura com sais minerais de MS (Tab.2), $10 \mathrm{mg} / \mathrm{L}$ de vitaminas MS (Tab.1), $100 \mathrm{mg} / \mathrm{L}$ inositol, $30 \mathrm{~g} / \mathrm{L}$ sacarose, $2 \mathrm{~g} / \mathrm{L}$ phytagel acrescido de uma das seguintes auxinas: dicamba $(10 \mu \mathrm{M})$, picloram (5 ou $10 \mu \mathrm{M}$ ), ácido naftaleno acético (NAA) (15 ou $20 \mu \mathrm{M}$ ), ácido 2,4-diclorofenoxiacético (2,4-D) (15 ou $20 \mu \mathrm{M}$ ), ou ausência de auxina. O meio foi solidificado com $2 \mathrm{~g} / \mathrm{L}$ phytagel e acertado o $\mathrm{pH} \mathrm{5,8}$ antes da autoclavagem a $121^{\circ} \mathrm{C}$ por $20 \mathrm{~min}$. $O$ experimento foi inteiramente casualizado com 8 tratamentos, incluindo-se a testemunha. Estruturas embriogênicas foram transferidas, após 4 semanas de cultivo no meio de indução, para o mesmo meio de cultura, porém, sem auxina, para desenvolvimento dos embriōes. As culturas foram mantidas em ausência de luz, à temperatura de $27 \pm 1^{\circ} \mathrm{C}$.

Amostras dos explantes foram coletadas aos 0,7 e 10 dias após inoculação em meio de indução. Posteriormente, aos 26 dias, coletaram-se amostras consistindo de regiões dos explantes onde estruturas embriogênicas 
se formaram (Fig. 1c) nos tratamentos com dicamba (10 $\mu \mathrm{M})$ e picloram (5 e 10 $\mu \mathrm{M})$, os quais responderam melhor ao processo de indução de embriogênese somática. Embriões somáticos provenientes das estruturas embriogênicas aos 26 e 34 dias e embriões zigóticos retirados de sementes maduras de Musa acuminata foram preparados para as comparações histológicas. Amostras foram preparadas para as análises histológicas, conforme ítem 3.4.1.

\subsubsection{Comparação entre diferentes meios de cultura e tempo necessário para a indução de embriogênese somática nas cvs. Nanicão e Ouro}

Três meios de cultura foram utilizados para indução de embriogênese somática: $1 / 2$ MS (Murashige \& Skoog, 1962), SH (Schenk \& Hildebrandt, 1972) e FN-Lite (Samoylov et al., 1998) (Tab. 3). A principal diferença entre os meios de cultura está na relação entre as fontes de nitrogênio nítrico e amoniacal $\left(\mathrm{NO}_{3}: \mathrm{NH}_{4}{ }^{+}\right)$. Aos sais minerais adicionaram-se $10 \mathrm{mg} / \mathrm{L}$ de vitaminas $\mathrm{MS}, 100$ $\mathrm{mg} / \mathrm{L}$ inositol, $30 \mathrm{~g} / \mathrm{L}$ sacarose, $10 \mu \mathrm{M}$ dicamba e $2 \mathrm{~g} / \mathrm{L}$ phytagel. A duração da fase de indução foi analisada, mantendo-se os explantes nestes meios por 2, 4 ou 6 semanas.

Utilizaram-se as cultivares comerciais de Musa spp Nanicão (grupo AAA) e Ouro (grupo AA). Os explantes foram mantidos em condições de escuro, em incubadora, à temperatura de $27 \pm 1^{\circ} \mathrm{C}$. 
Tabela 3. Fontes de Nitrogênio e respectivos teores em três meios de cultura

\begin{tabular}{lccc}
\hline Fonte de $\mathrm{N}$ & \multicolumn{3}{c}{ Meio de Cultura* (mM) } \\
\hline & $1 / 2 \mathrm{MS}$ & FN-Lite & $\mathrm{SH}$ \\
\cline { 2 - 4 } $\mathrm{NH}_{4} \mathrm{NO}_{3}$ & 10,3 & $-\cdots$ & $-\cdots$ \\
$\left(\mathrm{NH}_{4}\right)_{2} \mathrm{SO}_{4}$ & - & 3,5 & $-\cdots$ \\
$\mathrm{NH}_{4} \mathrm{H}_{2} \mathrm{PO}_{4}$ & - & - & 2,61 \\
$\mathrm{KNO}_{3}$ & 9,4 & 28,0 & 24,75 \\
$\left(\mathrm{NO}_{3}\right):\left(\mathrm{NH}_{4}\right)$ & $2: 1$ & $4: 1$ & $9,5: 1$ \\
\hline $\mathrm{Nitrogênio} \mathrm{Total}$ & 30,0 & 35,0 & 27,36 \\
\hline * $1 / 2 \mathrm{MS}=$ Meio de Murashige \& Skoog (1962) com metade dos sais macronutrientes; \\
FN-Lite = Meio FN, modificado por Samoylov et al. (1998); \\
$\mathrm{SH}=$ Meio de Schenk \& Hildebrandt (1972).
\end{tabular}

Após 2, 4 ou 6 semanas em meio de indução, as culturas foram transferidas para meio básico constituído de sais FN-Lite, acrescentando-se 10 $\mathrm{mg} / \mathrm{L}$ de vitaminas MS, $100 \mathrm{mg} / \mathrm{L}$ inositol, $30 \mathrm{~g} / \mathrm{L}$ sacarose, $2 \mathrm{~g} / \mathrm{L}$ phytagel, sem adição de reguladores vegetais, visando o desenvolvimento dos embriōes.

O experimento constou de blocos ao acaso em um fatorial de $2 \times 3 \times 3$, sendo 2 cultivares (Nanicao e Ouro), 3 meios de cultura (1/2 MS, FN-Lite e SH) e 3 tempos de indução (2, 4 ou 6 semanas), com 3 repetições por tratamento. Cada repetição foi constituída por uma placa de Petri com seis explantes. Cada bloco, portanto, era constituído de 18 tratamentos cada um com três repetições, totalizando 54 placas, sendo cada bloco instalado três vezes. A avaliação foi realizada contando-se $\circ$ número de explantes que responderam aos tratamentos, formando estruturas embriogênicas.

Baseando-se nos resultados obtidos o experimento foi repetido, desta vez em um fatorial $2 \times 3$, correspondendo as 2 cultivares (Nanicão e Ouro) e 3 meios de cultura (1/2 MS, FN-Lite e $\mathrm{SH}$ ), com um único periodo de indução, de 
quatro semanas. Cada tratamento constou de cinco repetições, sendo cada repetição composta por uma placa de Petri com seis explantes. O experimento foi instalado em blocos ao acaso, em um total de cinco blocos, totalizando 30 placas de Petri por bloco. O material foi avaliado observando-se a intensidade de resposta embriogênica em cada explante.

Após 4 semanas em meio de indução, as culturas foram transferidas para meio básico constituído de sais FN-Lite, acrescentando-se $10 \mathrm{mg} / \mathrm{L}$ de vitaminas MS, $100 \mathrm{mg} / \mathrm{L}$ inositol, $30 \mathrm{~g} / \mathrm{L}$ sacarose, $2 \mathrm{~g} / \mathrm{L}$ phytagel, sem adição de reguladores vegetais, visando o desenvolvimento dos embriões.

Amostras das culturas aos 30 dias foram coletadas para observação de suas características morfológicas e histológicas, através da microscopia ótica e eletrônica de varredura. As amostras foram preparadas conforme protocolos apresentados no item 3.4 .

\subsubsection{Maturação e germinação dos embriões somáticos}

Objetivando a obtenção de plantas, as estruturas embriogênicas formadas em meios de cultura FN-Lite, MS ou $1 / 2$ MS acrescidos de $10 \mu \mathrm{M}$ dicamba, $10 \mathrm{mg} / \mathrm{L}$ de vitaminas MS, $100 \mathrm{mg} / \mathrm{L}$ inositol, $30 \mathrm{~g} / \mathrm{L}$ sacarose e $2 \mathrm{~g} / \mathrm{L}$ phytagel, foram transferidas para meio de maturação. Os meios de maturação constituíam de sais FN-Lite contendo uma concentração mais elevada de sacarose $(60 \mathrm{~g} / \mathrm{L})$, ou acrescido de sacarose $(30 \mathrm{~g} / \mathrm{L})$ e polietilenoglicol (PEG + $30 \mathrm{~g} / \mathrm{L}$ sacarose), sendo denominados de $\mathrm{M} 1$ e $\mathrm{M} 2$, respectivamente. Ambos os meios de maturação foram suplementados com $10 \mathrm{mg} / \mathrm{L}$ de vitaminas $\mathrm{MS}$, $100 \mathrm{mg} / \mathrm{L}$ inositol, 0,44 $\mu \mathrm{M}$ BAP, 0,54 $\mu \mathrm{M}$ NAA, $500 \mathrm{mg} / \mathrm{L}$ carvão ativado e 2 $\mathrm{g} / \mathrm{L}$ phytagel. As culturas foram mantidas no escuro a $27 \pm 1^{\circ} \mathrm{C}$, por um periodo de 4 semanas.

Após o tratamento de maturação, os embriōes foram transferidos para meio de desenvolvimento constituído de sais de FN-Lite, $10 \mathrm{mg} / \mathrm{L}$ vitaminas de 
MS, $100 \mathrm{mg} / \mathrm{L}$ inositol, $30 \mathrm{~g} / \mathrm{L}$ sacarose e $2 \mathrm{~g} / \mathrm{L}$ phytagel, sem adição de reguladores vegetais. As culturas foram mantidas por 4 dias no escuro e, em seguida, colocadas em sala com fotoperiodo de 16 horas, sendo que as prateleiras onde colocaram-se o material, permaneceram com luzes apagadas, com luminosidade de apenas $4 \mu \mathrm{mol} \cdot \mathrm{m}^{-2} \cdot \mathrm{s}^{-1}$.

Após 4 a 8 semanas, os embriōes que apresentavam indícios de germinação foram transferidos para meio de cultura constituído de sais e vitaminas de MS, $100 \mathrm{mg} / \mathrm{L}$ inositol, solidificado com $2 \mathrm{~g} / \mathrm{L}$ phytagel e suplementado com $4,4 \mu \mathrm{M}$ BAP, permanecendo por 4 a 6 semanas a $27 \pm 2^{\circ} \mathrm{C}$ e fotoperiodo de 16 horas $\left(40 \mu \mathrm{mol} \cdot \mathrm{m}^{-2} \cdot \mathrm{s}^{-1}\right)$. Em seguida, as plântulas obtidas foram transferidas para meio de cultura MS sem reguladores vegetais, para crescimento e posterior aclimatação. As plântulas obtidas foram aclimatadas em vermiculita por 4 semanas e com umidade relativa elevada, através de nebulização. Após o enraizamento, as plântulas foram transferidas para substrato comercial e colocadas em casa de vegetação. Com cerca de $50 \mathrm{~cm}$ de altura, as mudas foram plantadas no campo.

Amostras de embriōes somáticos induzidos em meio de sais $1 / 2 \mathrm{MS}$, acrescido de $10 \mu \mathrm{M}$ dicamba e transferido para meio de maturação FN-Lite, suplementado com $30 \mathrm{~g} / \mathrm{L}$ sacarose e $30 \mathrm{~g} / \mathrm{L}$ PEG, foram coletados para observação ao microscópio eletrônico de varredura. O preparo das amostras foi realizado conforme item 3.4.2.

\subsection{Embriogênese somática a partir de inflorescências funcionalmente masculinas}

a) Preparo dos explantes: Parte da inflorescência (dicásios) de bananeira do setor ândrico ("coração") de cultivares Nanicão Jangada e Grand Nain (Musa spp, grupo AAA), foi coletada logo após a formação do último dicásio (última "penca"), de plantas em plantio comercial localizado na região de Monte Alto, 
SP. O "coração" foi reduzido a cerca de $10 \mathrm{~cm}$ de comprimento, com a retirada de várias brácteas e dicásios, sendo submetido a assepsia em solução comercial de hipoclorito de sódio (2:1), durante 30 minutos, seguido de lavagem em água destilada esterilizada por 3 vezes, em câmara de fluxo laminar. Dicásios funcionalmente masculinos das posições 1 a 15 (zero correspondendo ao meristema floral) (Figs. 1d,e), foram isolados com o auxílio de microscópio estereoscópico e utilizados como explantes para indução de embriogênese somática. Os dicásios eram compostos de botões florais, tendo o dicásio da posição 15 , aproximadamente, $5 \mathrm{~mm}$ de comprimento.

b) Condições de Indução: As inflorescências foram inoculadas em placas de Petri $(60 \times 15 \mathrm{~mm})$ contendo meio $\mathrm{MI}$, composto de sais e vitaminas de MS (Murashige \& Skoog, 1962), suplementado com 1,34 $\mu \mathrm{M}$ ácido indolacético (IAA), $18 \mu \mathrm{M}$ ácido 2,4-diclorofenoxiacético (2,4-D), 5,4 $\mu \mathrm{M}$ ácido naftaleno acético (NAA), $30 \mathrm{~g} / \mathrm{L}$ sacarose e solidificado com $7 \mathrm{~g} / \mathrm{L}$ ágar, conforme Escalant et al. (1994). Inicialmente, foram utilizadas as cultivares Grand Nain e Nanicão Jangada, ambas do grupo AAA, sendo testada indução tanto no escuro, como em fotoperíodo de 16 horas sob intensidade luminosa de $4 \mu \mathrm{mol}$ $\mathrm{m}^{-2} \mathrm{~s}^{-1}$, a $27 \pm 2^{\circ} \mathrm{C}$ (Tab. 4). Devido à grande oxidação dos explantes induzidos no claro, optou-se, no experimento seguinte, pela manutenção das culturas no escuro, utilizando-se explantes somente da cultivar Nanicão Jangada, pela disponibilidade de material no campo. Após 10 a 12 semanas em meio de indução, o material (explantes e embriões somáticos obtidos) foi transferido para meio de germinação MG, o qual consiste de sais de $M S$, vitaminas de Morel, $30 \mathrm{~g} / \mathrm{L}$ sacarose, solidificado com $2 \mathrm{~g} / \mathrm{L}$ phytagel e suplementado com $0,22 \mu \mathrm{M}$ benzilaminopurina (BAP) e 1,14 $\mu \mathrm{M}$ IAA, conforme Escalant et al.

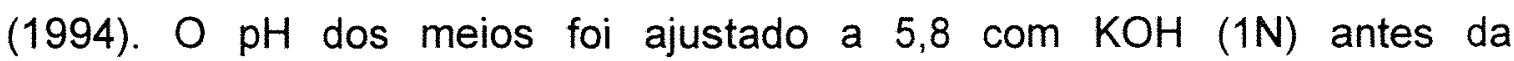
autoclavagem a $121^{\circ} \mathrm{C}$ por $20 \mathrm{~min}$. 
Amostras da inflorescência e das culturas após o período de indução foram coletadas e preparadas para observação em microscópio ótico, conforme item 3.4 .

Tabela 4. Total de dicásios (explantes) de inflorescência introduzidos em cada experimento para indução de embriogênese somática em bananeira.

\begin{tabular}{lcc}
\hline Cultivar & $\mathbf{N}^{\circ}$ de dicásios & Condição de cultivo \\
\hline Grand Nain & 105 & 16h fotoperiodo $\left(4 \mu \mathrm{mol} \cdot \mathrm{m}^{-2} \cdot \mathrm{s}^{-1}\right)$ \\
& 150 & Escuro \\
Nanicão Jangada & 150 & $16 \mathrm{~h}$ fotoperiodo $\left(4 \mu \mathrm{mol} \cdot \mathrm{m}^{-2} \cdot \mathrm{s}^{-1}\right)$ \\
& 720 & Escuro \\
\hline
\end{tabular}

\subsection{Preparo das amostras para análises microscópicas}

\subsubsection{Microscopia ótica}

As amostras foram fixadas por um período mínimo de 8 horas em solução de paraformaldeído $(3 \%, \mathrm{p} / \mathrm{v})$ e glutaraldeído $(2 \%, \mathrm{v} / \mathrm{v})$ em cacodilato de sódio $0,2 \mathrm{M}, \mathrm{pH} 7,2$, sob refrigeração (Rodriguez \& Wetzstein, 1998). Os tecidos fixados foram lentamente desidratados à temperatura ambiente em uma série crescente de etanol, seguido de imersão em etanol:meio de infiltração (1:1) durante a noite, a $4^{\circ} \mathrm{C}$. Em seguida, as amostras foram transferidas para meio de infiltração, permanecendo por $24 \mathrm{~h}$, ou até que as amostras ficassem translúcidas e no fundo do recipiente $\left(4^{\circ} \mathrm{C}\right)$. Para infiltração e emblocagem utilizou-se $\circ$ kit Historesina (hidroxietilmetacrilato, Leica, Heidelberg). A 
polimerização foi feita à temperatura ambiente por 24 a $48 \mathrm{~h}$. Cortes seriados com espessura de $3-5 \mu \mathrm{m}$ foram realizados e corados com azul de toluidina (1\%), ou com fucsina ácida (5\%) seguida de azul de toluidina (1\%) (Feder \& O'Brien, 1968).

\subsubsection{Microscopia eletrônica de varredura}

As amostras foram fixadas em glutaraldeído $4 \%$ em cacodilato de sódio $0,1 \mathrm{M}$ a $4^{\circ} \mathrm{C}$, sob vácuo durante as 2 primeiras horas e depois mantidos sob refrigeração durante a noite. Em seguida as amostras foram lavadas em cacodilato de sódio $(0,1 \mathrm{M})$ e desidratadas em uma série de concentrações crescentes de etanol (35 a 100\%), seguido de secagem ao ponto crítico através de $\mathrm{CO}_{2}$ líquido (Rodriguez \& Wetzstein, 1998). As amostras secas foram preparadas nos suportes, cobertas com ouro, observadas e fotografadas em microscópio eletrônico de varredura (Zeiss, DSM 940A) operando entre 10 e 15 $k V$. 


\section{RESULTADOS E DISCUSSÃO}

\subsection{Embriogênese somática a partir de explantes de ápice vegetativo}

\subsubsection{Comparação do efeito de diferentes auxinas na indução de embriogênese somática na cv. Nanicão}

Cortes histológicos realizados nos explantes no momento da introdução em meio com auxina, evidenciaram que estes eram constituidos de tecido parenquimático circundando a região do cilindro central, esta constituída de células parenquimáticas e feixes vasculares (Fig. 2a). Nos tratamentos com NAA, 7 dias após a introdução, observou-se a ausência de formação de regiões morfogênicas, sendo o tecido basicamente constituído por células parenquimáticas e feixes vasculares (Fig. 2b), semelhante ao explante no momento da introdução em meio de indução. Cortes histológicos aos 7 dias do material inoculado em meio com 2,4-D, apresentaram discretas regiöes com características morfogênicas (Fig. 2c). Os explantes inoculados em meio contendo picloram apresentaram regiōes com atividade mitótica mais intensa (Fig. 2d). Estas foram observadas principalmente na região pericíclica. No tratamento com dicamba, observou-se nesta mesma região, intensa atividade mitótica (Fig. 2e), caracterizada pela presença de células pequenas, com núcleo relativamente grande e reduzida vacuolização, características típicas de regiões morfogênicas. Aos 7 dias após a indução em meio com dicamba, já pode-se visualizar regiões embriogênicas em início de formação de pró- 
embriões (Fig. 2f).

Análise do material em ausência e presença de auxinas, aos 15 e 30 dias, confirmou as observações histológicas na testemunha e tratamentos com NAA (Tab. 5). Na testemunha (ausência de regulador vegetal), observou-se somente o crescimento de raízes e gemas, pré-existentes no explante. Resultado semelhante foi verificado em meio contendo NAA (15 e $20 \mu \mathrm{M}$ ) (Fig 3a), demonstrando a ineficiência desses tratamentos para a indução de embriogênese somática em explantes de bananeira. Nos meios acrescidos de 2,4-D (15 e $20 \mu \mathrm{M}$ ), visualmente não se observou resposta embriogênica (Figs. $3 \mathrm{~b}, \mathrm{c})$, havendo elevada oxidação dos explantes, principalmente na dose mais alta. Aparentemente, $\mathrm{o}$ início de atividade meristemática observada através dos cortes histológicos, aos 7 dias (Fig. 2c) cessou, já que não se observou a proliferação de estruturas embriogênica nos explantes. Ao contrário do NAA, o 2,4-D, em ambas as doses, bloqueou o desenvolvimento normal dos explantes, ou seja, o crescimento de gemas e raízes.

Tabela 5. Resposta (\%) de explantes de bananeira, cv. Nanicão, aos tratamentos de indução de embriogênese somática com diferentes auxinas, 15 e 30 dias após a inoculação.

\begin{tabular}{lcccc}
\hline \multirow{2}{*}{$\begin{array}{l}\text { Auxina } \\
(\mu \mathrm{M})\end{array}$} & \multicolumn{2}{c}{ Estruturas embriogênicas } & \multicolumn{2}{c}{ Raízes / Gemas } \\
\cline { 2 - 5 } & $\mathbf{1 5}$ dias & $\mathbf{3 0}$ dias & 15 dias & 30 dias \\
\hline Ausência & 0 & 0 & 49,6 & 58,7 \\
NAA (15) & 0 & 0 & 46,0 & 56,4 \\
NAA (20) & 0 & 0 & 36,3 & 46,5 \\
2,4-D (15) & 0 & 0 & 0 & 0 \\
2,4-D (20) & 0 & 0 & 0 & 0 \\
Picloram (5) & 65,7 & 100,0 & 0 & 0 \\
Picloram(10) & 59,0 & 100,0 & 0 & 0 \\
Dicamba (10) & 0 & 80 & 0 & 0 \\
\hline
\end{tabular}



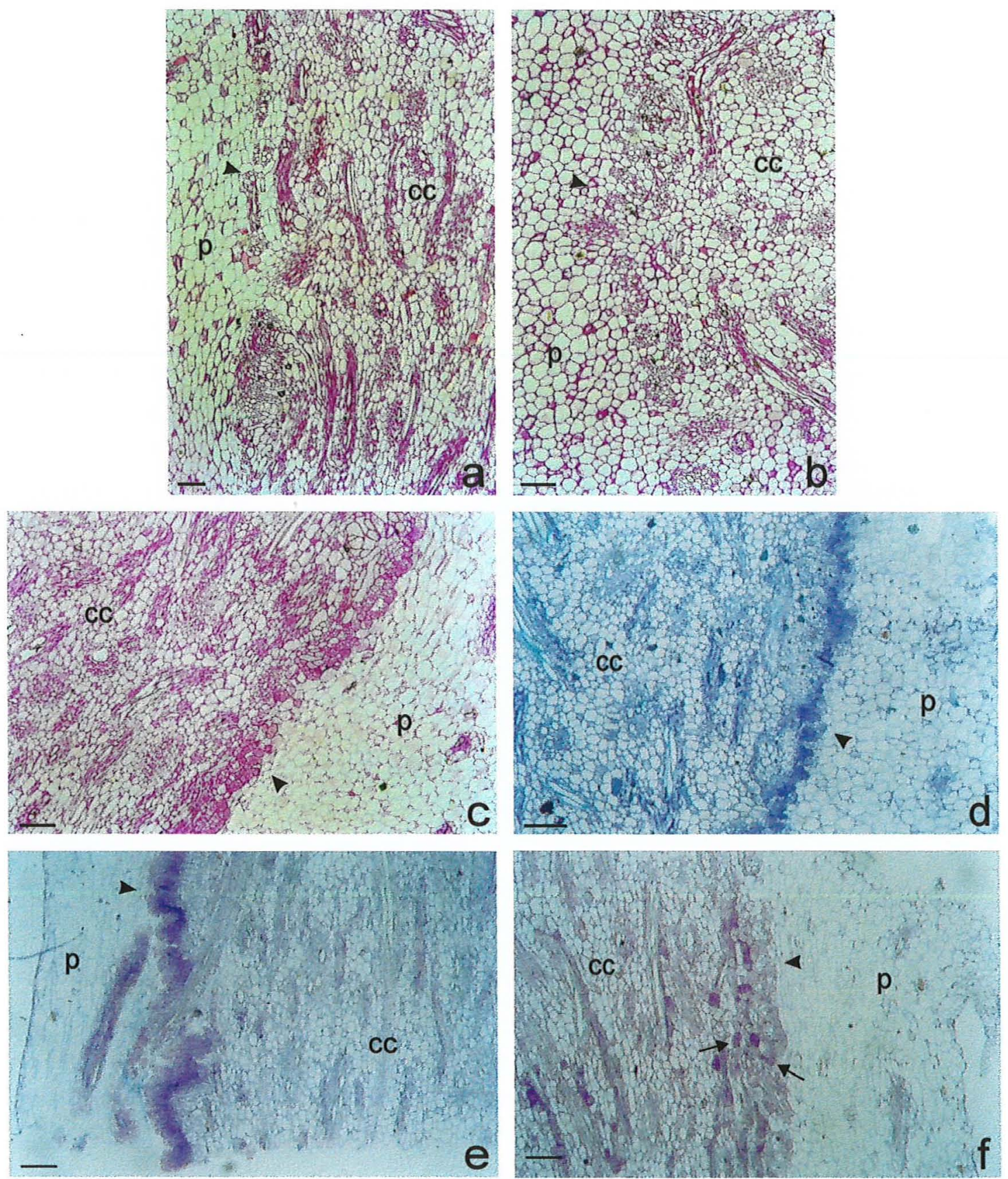

Figura 2. Seções longitudinais de ápices vegetativos de bananeira, cv. Nanicão, em meio MS contendo diferentes auxinas, para indução de embriogênese somática. a) explante no momento da introdução, mostrando tecido constituído de células parenquimáticas e feixes vasculares; $b$-f) explantes após 7 dias em meio contendo b) $20 \mu \mathrm{M} \mathrm{NAA}$, mostrando ausência de atividade meristemática; c) $20 \mu \mathrm{M} 2,4-\mathrm{D}$, com pequena área com atividade mitótica; d) $10 \mu \mathrm{M}$ picloram, com presença de áreas com atividade mitótica mais intensa; ef) dicamba $10 \mu \mathrm{M}$, mostrando intensa atividade mitótica, caracterizada pela presença de células pequenas, denso citoplasma e reduzida vacuolização (e), regiōes embriogênicas em início de formação de pró-embriōes $(f)$. $(p=$ parênquima cortical; $c c=$ cilindro central; ponta de seta = regiäo pericíclica; seta = pró-embriöes). Barras $200 \mu \mathrm{m}(2 \mathrm{a}-\mathrm{f})$. 
Resultados positivos, com formação de estruturas embriogênicas, foram visualizados em explantes inoculados em meio contendo ambas as doses de picloram (5 e $10 \mathrm{mM}$ ) (Fig. 3d,e) e dicamba (10 mM) (Fig. 3f), diferenciando-se esses tratamentos pela intensidade de indução e o tempo após a inoculação para o início da formação dessas estruturas (Tab. 6). Aos 14 dias em picloram, os explantes já apresentavam estruturas embriogênicas, enquanto que em dicamba, somente aos 21 dias estas foram observadas. Embora a atividade meristemática tenha se iniciado antes no tratamento com dicamba $(10 \mu \mathrm{M})$ (Fig.2), as estruturas embriogênicas formaram-se mais cedo nos tratamentos com picloram (5 e $10 \mathrm{mM}$ ) (Fig. 3d,e). Em meio com picloram, a quantidade das estruturas embriogênicas foram aparentemente superiores, em relação ao tratamento com dicamba. Apesar de ter sido utilizado com sucesso em experimentos anteriores (Novak et al., 1989; Lee et al.,1997), neste experimento o tratamento com dicamba apresentou um declínio na formação de estruturas embriogênicas, com oxidação parcial após três semanas em meio de indução. Isto sugere a necessidade de maiores estudos, incluindo alterações no período de exposição ao meio de indução.

Tabela 6. Início da formação de estruturas embriogênicas em explantes de bananeira 'Nanicão' tratados com auxinas.

\begin{tabular}{lc}
\hline Auxina $(\mu \mathrm{M})$ & Dias após a inoculação \\
\hline Picloram (5) & 14 \\
Picloram(10) & 14 \\
Dicamba (10) & 21 \\
\hline
\end{tabular}



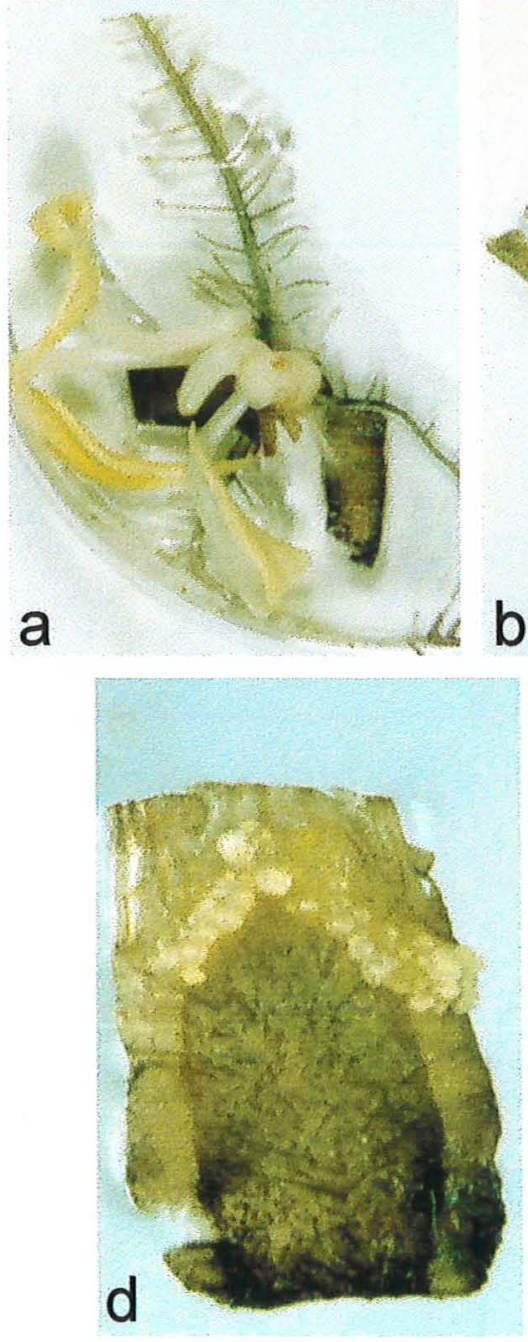
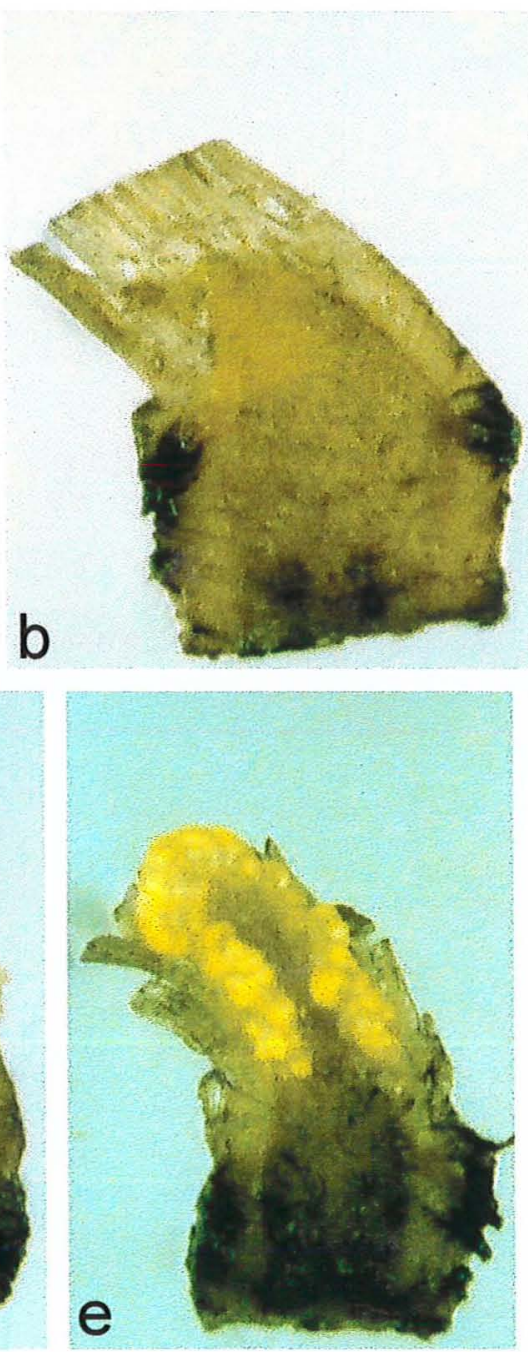
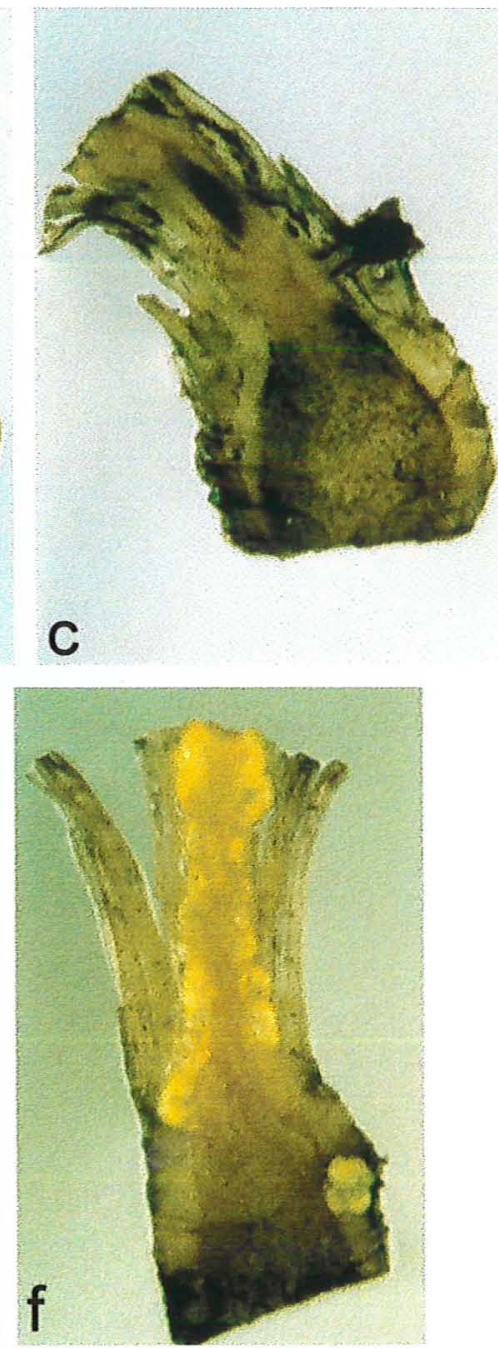

Figura 3. Explantes de ápice vegetativo de bananeira, cv. Nanicão, após 30 dias em meio MS contendo diferentes auxinas para indução de embriogênese somática. a) crescimento de gemas e raízes pré-existentes no explante em meio com $20 \mu \mathrm{M}$ NAA; b-c) ausência de resposta embriogênica em meio com $15 \mu \mathrm{M} 2,4-\mathrm{D}$ (b) e $20 \mu \mathrm{M}$ 2,4-D (c); d-f) formação de estruturas embriogênicas em meio contendo $5 \mu \mathrm{M}$ picloram (d), $10 \mu \mathrm{M}$ picloram (e)e $10 \mu \mathrm{M}$ dicamba (f) (base do explante com 0,5 a 1,0 cm). 
O tipo de explante utilizado, mostrou-se adequado para a indução de embriogênese somática, associado ao uso de picloram ou dicamba. Observouse, em estudos preliminares, que a espessura dos explantes é importante no processo, sendo que os explantes com espessura de aproximadamente $1 \mathrm{~mm}$ apresentaram melhor resposta, em relação aos explantes mais espessos. Cortes histológicos realizados aos 26 dias em meio contendo dicamba mostraram, no mesmo explante, duas formações: regiões embriogênicas com formação de pró-embriōes (Fig. 4a, ponta de seta), e regiōes meristemáticas não organizadas, com elevada atividade mitótica (Fig. 4a, seta). Essas regiões meristemáticas não organizadas, possivelmente deram origem a calos não embriogênicos, ou a estruturas não embriogênicas, algumas delas aparentemente formando diversos ápices radiculares (Fig. 4b).

Os pró-embriões observados nas regiões embriogênicas apresentavamse em diversos tamanhos, em região composta por células parenquimáticas, geralmente próximas a elementos de vaso do xilema (Fig. 4c). Os pró-embriões possuiam células compactas, ricas em amido, com núcleo e nucléolo proeminente e reduzida vacuolização, apresentando, aparentemente, individualização em relação as células parenquimáticas vizinhas (Fig. 4d). Yeung (1995), comenta sobre a necessidade de isolamento dos embriões globulares para que seu desenvolvimento ocorra.

Em fases seguintes, embriōes somáticos foram observados na superfície dos explantes, destacando-se facilmente destes. Os embriões somáticos observados apresentaram-se como estruturas morfologicamente semelhantes a embriões zigóticos de Musa acuminata (Fig. 5a), os quais possuem uma região apical de maior diâmetro, formada pelo haustório, e uma região basal de diâmetro menor, de onde se formam os ápices caulinar e radicular. 

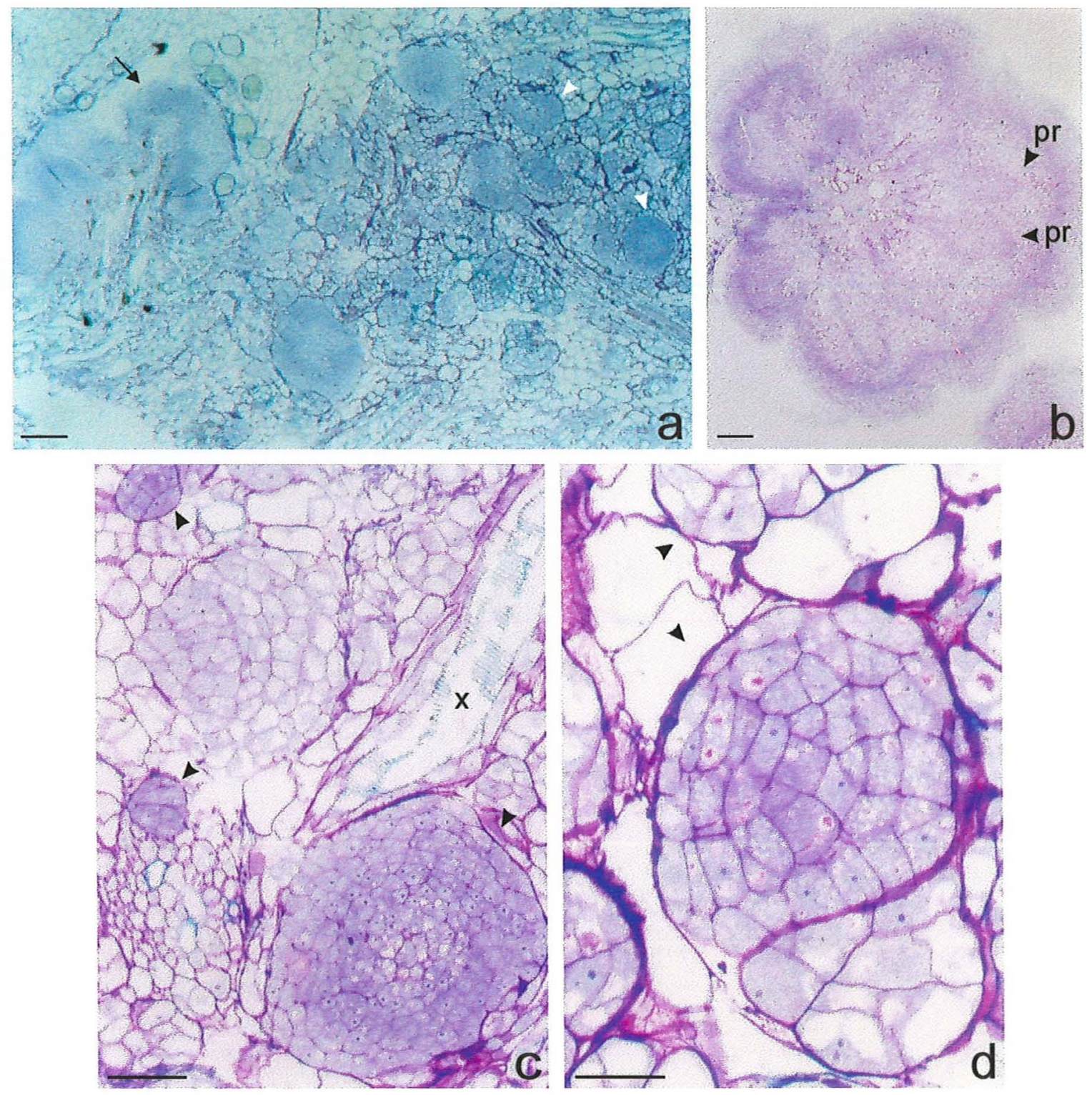

Figura 4. Seçöes longitudinais de explante de bananeira, cv. Nanicäo, 26 dias após a introdução em meio MS contendo $10 \mu \mathrm{M}$ dicamba. a) explante mostrando tanto regiöes embriogênicas com formação de pró-embriōes (ponta de seta), como regiöes meristemáticas não organizadas, com elevada atividade mitótica (seta); b) estrutura desenvolvida aos 34 dias em meio contendo $10 \mu \mathrm{M}$ dicamba, mostrando diferenciação de vários primórdios radiculares (pr), possivelmente, originários das regiões meristemáticas não organizadas; $\mathrm{c}-\mathrm{d}$ ) próembriőes (ponta de seta) localizados próximo a elemento de vaso do xilema (x) (c), e individualizados em relação as células parenquimáticas vizinhas (d). Barras $=200 \mu \mathrm{m}(4 \mathrm{a}-\mathrm{b}) ; 50 \mu \mathrm{m}(4 \mathrm{c}-\mathrm{d})$. 
McGahan (1961) apresenta detalhes da anatomia do embrião zigótico de Musa balbisiana. Neste, encontra-se a região do haustório, caracterizada por grandes espaços intercelulares, constituindo a principal parte do cotilédone. $O$ procâmbio localiza-se em toda a região do embrião, formando faixas na região do haustório (McGahan, 1961). Cortes histológicos realizados em embriões zigóticos de Musa acuminata (Fig. 5a), apresentam características anatômicas muito semelhantes àquelas apresentadas por McGahan (1961), comprovando a semelhança entre os embriões zigóticos de Musa balbisiana e M. acuminata.

Cortes histológicos dos embriões somáticos que se assemelham morfologicamente ao embrião zigótico de Musa acuminata, mostraram ausência de histodiferenciação dos meristemas apicais, procâmbio e da protoderme, além de ausência de acúmulo de substâncias de reserva (Fig. $5 b$ ). A região do haustório no embrião zigótico (Fig. 5a) apresenta células com reduzida vacuolização, citoplasma denso, enquanto que nos embriōes somáticos a mesma região apresenta células com um vacúolo central ocupando grande parte da área celular, descartando-se a possibilidade de serem células de reserva (Fig. 5b). Formação de faixas procambiais, ápice meristemático caulinar e primórdio foliar são visiveis nos embriōes zigóticos (Fig. $5 \mathrm{a}$ ), porém ausentes nos embriões somáticos (Fig. 5b).

Estruturas embriogênicas dos tratamentos com picloram e dicamba transferidas para meio líquido em ausência de auxina apresentaram despreendimento de embriões somáticos. Conversão desses embriões em plantas, porém, não foi obtida neste experimento, provavelmente pela ausência de desenvolvimento do meristema caulinar. Caracteristicas semelhantes foram verificadas por Lee et al (1997), com Musa spp, e Nickle \& Yeung (1993), em Daucus carota. 

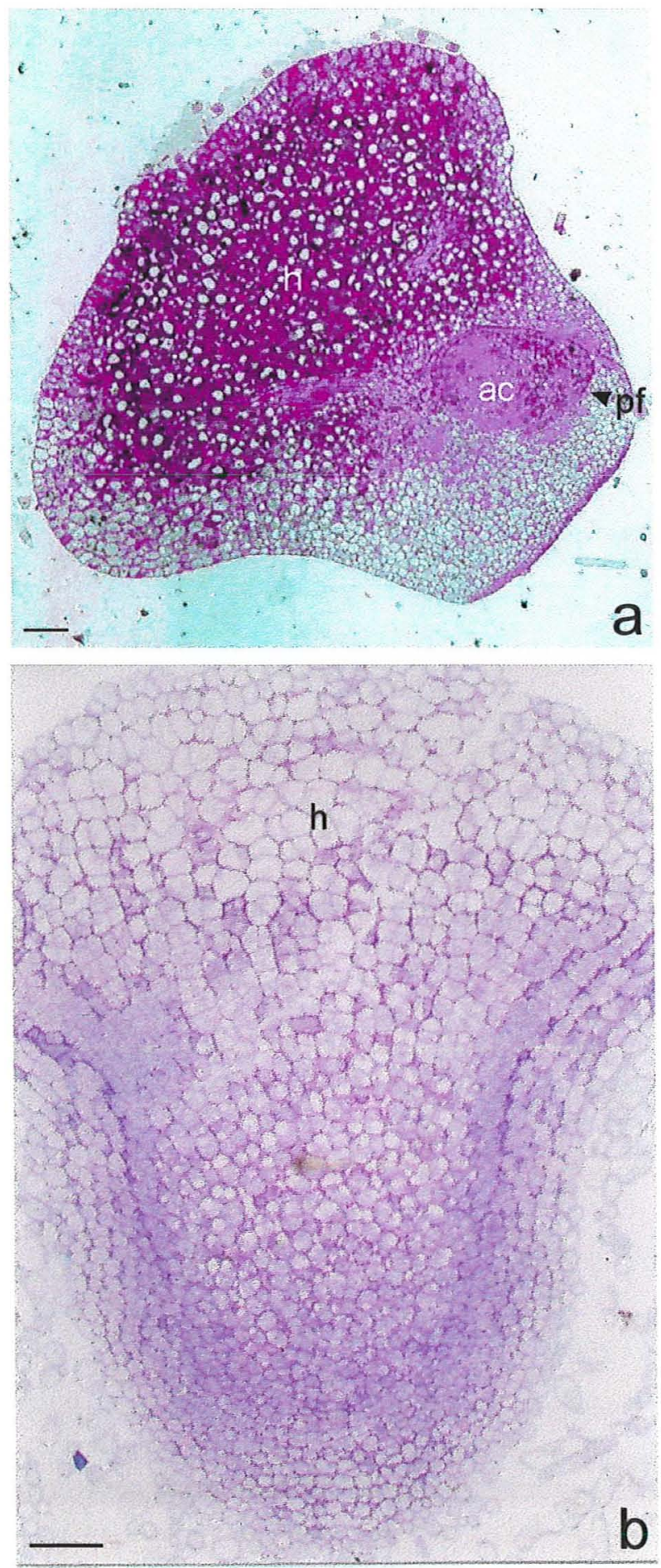

Figura 5. Seção longitudinal de embrião zigótico de Musa acuminata (a); embrião somático de bananeira, cv. Nanicão, aos 27 dias em meio MS contendo $10 \mu \mathrm{M}$ picloram, com morfologia semelhante ao embrião zigótico, porém com ausência de histodiferenciação (b); ( $h$ = haustório; ac = ápice caulinar; pf = primórdio foliar). Barras $=100 \mu \mathrm{m}(5 \mathrm{a}-\mathrm{b})$. 
Fischer \& Neuhaus (1996), verificaram um bloqueio do meristema caulinar em embriões somáticos de Triticum aestivum induzidos com 2,4,5-T, devido à alta vascularização das células deste meristema. Segundo esses autores, o estabelecimento da polaridade representa o início de desenvolvimento das principais estruturas embriogênicas em monocotiledôneas: o eixo embriogênico e o escutelo. O transporte polar da auxina no estágio inicial do embrião globular é essencial para o estabelecimento da simetria bilateral (Liu at al., 1993), podendo esta ser comprometida, caso ocorra uma homogeneização da distribuição de auxina no próprio embrião, devido ao aumento deste hormônio em nivel endógeno pela presença de auxina exógena (Fischer \& Neuhaus,1996). A adequação do tempo e da concentração de auxina utilizada na fase de indução, associada ao estágio de maturação do embrião, o qual permite o estabelecimento e desenvolvimento do meristema caulinar, são essenciais para qualidade do embrião somático, visando a conversão em plântulas.

Um dos passos importantes da embriogênese, e que marca o início da histodiferenciação do embrião somático é a formação da protoderme (Yeung, 1995), que é o tecido de revestimento do embrião. Neste experimento, além da falta da diferenciação do meristema caulinar, não se verificou a formação completa da protoderme, visualizando-se apenas o que parece ser o início da diferenciação da protoderme (Fig. $5 b$ ), associada a células vacuolizadas ao redor do embrião, sendo estes sinais que indicam necessidade de alterações na fase de indução. Yeung (1995) comenta sobre a importância da protoderme para o desenvolvimento do embrião somático. Segundo este autor, há observações de paralização no desenvolvimento de embriões somáticos de cenoura ocasionada pela formação anormal da protoderme.

Estudos mais detalhados deverão ser realizados, visando a formação de embriōes de melhor qualidade, os quais poderão apresentar maior facilidade de conversão em plantas. A qualidade do embrião somático associada às fontes 
de nitrogênio nítrico e amoniacal, tempo de indução, bem como estágio de maturação, são requisitos fundamentais para a eficiência da embriogênese somática, visando a conversão em plantas.

\subsubsection{Comparação entre diferentes meios de cultura e tempo necessário para indução de embriogênese somática nas cvs. Nanicão e Ouro.}

Início de multiplicação celular, principalmente nas região pericíclica, foi observada após dez a doze dias em meio de indução, aproximando-se do verificado na indução com picloram do experimento anterior. Após duas semanas, avaliaram-se os tratamentos (Tab. 7), observando-se diferença de resposta entre meios de cultura e cultivares. Para a cv. Ouro, o percentual de resposta foi significativamente maior, comparado à cv. Nanicão, indicando um início de resposta mais rápido. Após quatro semanas, porém, observou-se resposta embriogênica similar para ambas as cultivares, em relação ao número de explantes responsivos (Tab. 7). Apesar de serem pequenas as diferenças entre os tratamentos, em relação ao número de explantes responsivos, a qualidade dos embriões somáticos foi diferenciada, principalmente no meio de cultura $\mathrm{SH}$, em relação aos outros dois meios. 
Tabela 7. Percentual de resposta de formação de estruturas embriogênicas em explantes de ápices vegetativos de Musa spp, cultivados em diferentes meios de cultura suplementados com $10 \mu \mathrm{M}$ dicamba.

\begin{tabular}{lcccc}
\hline Cultivar & Tratamentos & \multicolumn{3}{c}{ Estruturas embriogênicas (\%) } \\
\cline { 3 - 5 } & & \multicolumn{3}{c}{ Semanas de indução } \\
\hline \multirow{4}{*}{ Nanicão } & FN-Lite & $46,3 \pm 1,39$ & $87,0 \pm 0,67$ & $96,3 \pm 0,44$ \\
& SH & $46,3 \pm 1,09$ & $90,7 \pm 0,53$ & $92,6 \pm 0,73$ \\
& $1 / 2$ MS & $38,8 \pm 0,70$ & $85,2 \pm 0,78$ & $72,2 \pm 1,12$ \\
& & & & \\
Ouro & FN-Lite & $85,2 \pm 0,78$ & $90,7 \pm 1,13$ & $88,8 \pm 1,33$ \\
& SH & $83,3 \pm 0,87$ & $90,7 \pm 1,34$ & $96,3 \pm 0,67$ \\
& $1 / 2$ MS & $66,6 \pm 0,87$ & $87,0 \pm 1,39$ & $90,7 \pm 1,02$ \\
\hline
\end{tabular}

A qualidade morfológica e anatômica dos embriões somáticos obtidos, diferem em relação aos meios de cultura utilizados (Fig. 6). Análise das culturas em meios 1/2 MS (Figs. 6 a,b) e FN-Lite (Fig. 6d) após 4 semanas de indução, mostrou a formação de calos embriogênicos e embriões pequenos, agrupados, com coloração amarelada e formato de "cogumelo", apresentando semelhança morfológica com embriōes zigóticos de Musa spp. As culturas em meio $\mathrm{SH}$, caracterizaram-se pela formação de calo esbranquiçado, mais friável e por apresentar embriões somáticos maiores, com aspecto friável e de coloração esbranquiçada (Fig. 6c). 

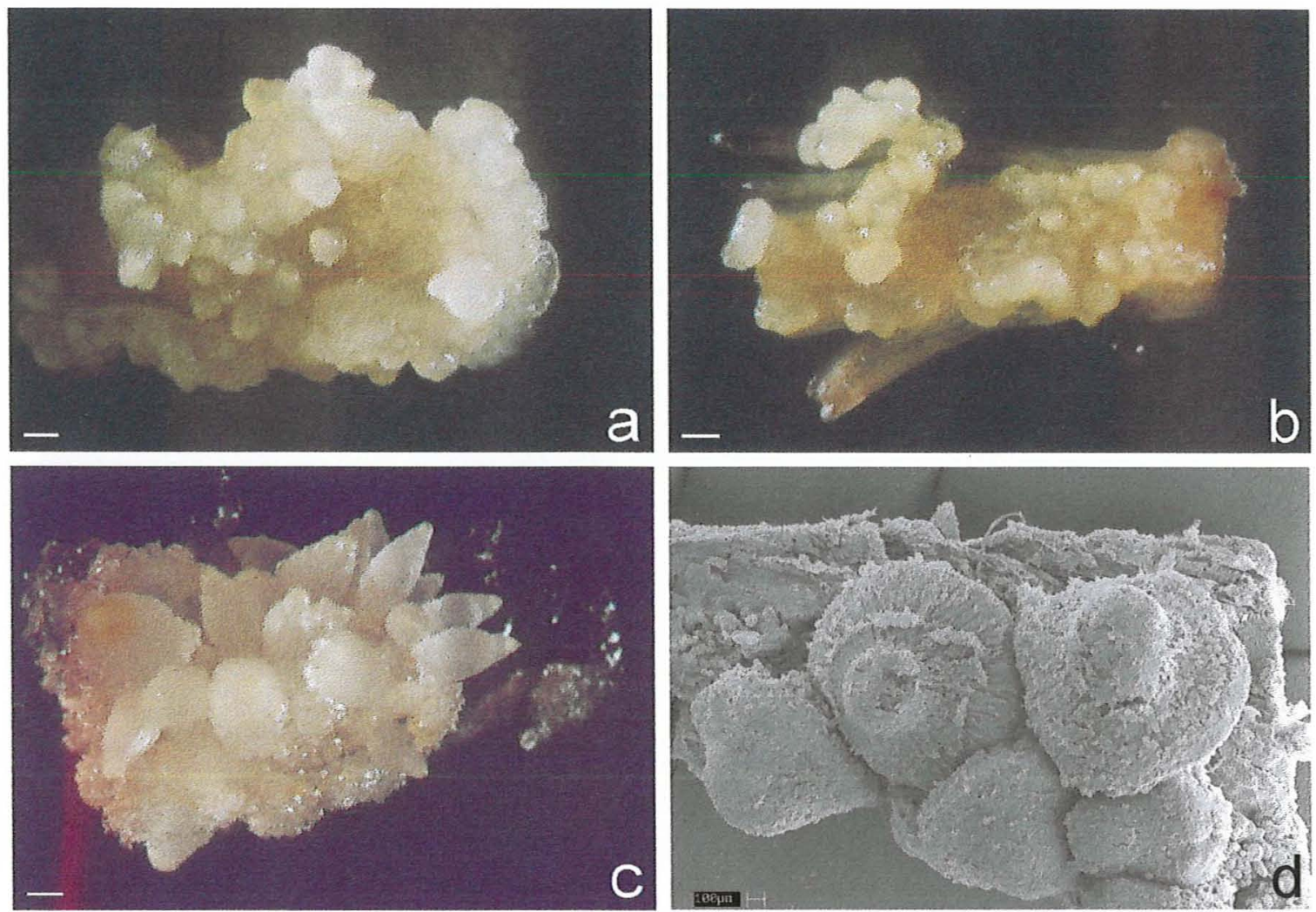

Figura 6. Estruturas embriogênicas de Musa spp formadas a partir de ápices vegetativos, após 4 semanas em meios de indução contendo diferentes fontes de nitrogênio nítrico e amoniacal $\left(\mathrm{NO}_{3}{ }^{-} \mathrm{NH}_{4}{ }^{+}\right)$. a-b) embriōes somáticos pequenos, amarelados e com formato de cogumelo em meio $1 / 2$ MS nas cvs. Ouro (a) e Nanicão (b); c) embriőes somáticos maiores, com aspecto friável e de coloração esbranquiçada em meio SH da cv. Nanicão; d) micrografia de MEV da cv. Nanicão, mostrando embriöes somáticos sobre o explante em meio FNLite. Barras $=1 \mathrm{~mm}(6 \mathrm{a}-\mathrm{c})$. 
Cortes histológicos de embriões somáticos em meio $1 / 2 \mathrm{MS}$, mostraram ausência de histodiferenciação do procâmbio e meristemas apicais. Não se observou na superfície das estruturas formação de um tecido completo de revestimento, mas de várias células com crescimento desordenado, ou um início da diferenciação da protoderme (Fig. $7 b$ ). Características semelhantes foram observadas em embriōes somáticos induzido em meio MS contendo $10 \mu \mathrm{M}$ picloram (Fig. $5 \mathrm{~b}$ ). Em alguns casos, na região basal do embrião somático (Fig. 7b) observou-se uma região meristemática, possivelmente indicando início de diferenciação do meristema apical caulinar, porém as células ao redor desta região são mais vacuolizadas, com reduzido acúmulo de substâncias de reserva e apresentam espaços intercelulares. Lee et al. (1997), observaram regiōes de maior intensidade de divisões celulares em embriões somáticos de bananeira aos 50 dias em meio de indução, provavelmente correspondendo à região onde se formaria a plúmula.

Cortes histológicos dos embriões somáticos em meio SH (Fig. 7c,d), mostraram células altamente vacuolizadas, com grandes espaços intercelulares e uma reduzida área basal, com células pequenas, com maior intensidade mitótica, porém sem diferenciação de tecidos.

Entre os fatores que afetam a embriogênese somática, o período de exposição à auxina (Parrott et al., 1988), e o balanço e tipo de fontes nitrogenadas (Nomura e Komamine, 1995) podem desempenhar papel importante na indução de embriões somáticos.

Neste experimento, considerando-se o percentual de explantes responsivos e a qualidade dos embriões somáticos, o período adequado de indução foi de 4 semanas, onde já se tem uma quantidade estabilizada de estruturas embriogênicas formadas. Pelos resultados obtidos no experimento com a cultivar Ouro, pode-se recomendar um período de indução mais curto, de 2 semanas, podendo, neste caso, diminuir o efeito prejudicial da auxina no desenvolvimento do embrião somático. A permanência prolongada dos 
explantes no meio com auxina, pode prejudicar a histodiferenciação do embrião somático, afetando a formação do meristema caulinar. Observação similar foi feita por Parrott et al. (1988) o qual demonstrou que o tempo de exposição à auxina, foi inversamente proporcional ao desenvolvimento do embrião somático de soja (Glicine max).

Pelas análises morfo-anatômicas dos embriões somáticos de Musa spp obtidos nos três diferentes meios de cultura, observou-se que apesar do número de explantes responsivos ter sido semelhante nos tratamentos, após 4 semanas, os embriões formados nos meios de cultura com menor razão $\mathrm{NO}_{3}^{-}$ $: \mathrm{NH}_{4}^{+}$, referente aos meios $1 / 2 \mathrm{MS}$ e FN-Lite, apresentaram-se com melhor qualidade.

As estruturas embriogênicas formadas sobre os explantes, foram transferidas após 2, 4 ou 6 semanas de indução para meio de sais FN-Lite, sem adição de reguladores vegetais, visando o desenvolvimento dos embriões. No entanto, observou-se que em todos os períodos após a retirada da auxina, houve um desenvolvimento preferencial do ápice radicular. A tendência de formar raíz, aumentava com o tempo de exposição do embrião no meio de indução, o mesmo observado por Trigiano et al., (1988), em embriões somáticos de Cercis canadensis. Provavelmente, esta formação ocorreu pela baixa qualidade dos embriões somáticos, associada a falta de histodiferenciação do meristema apical caulinar. Falha estrutural ou funcional do meristema caulinar, também foi observada em outros protocolos de embriogênse somática (Trigiano et al., 1988; Nickle \& Yeung, 1993; Padmanabhan et al., 1998). 

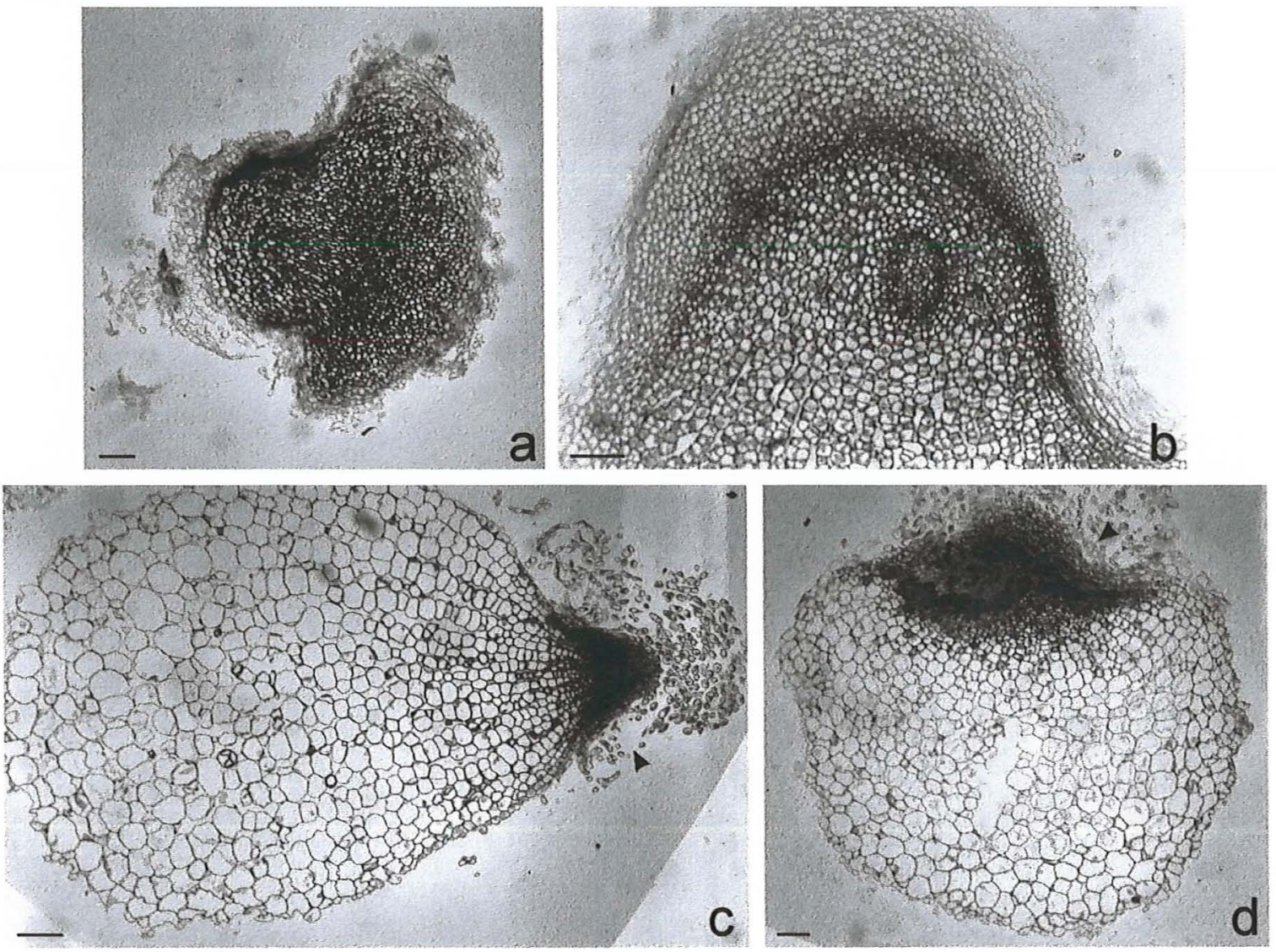

Figura 7. Cortes histológicos de estruturas embriogênicas de Musa spp formadas a partir de ápice vegetativo após 4 semanas de indução. a-b) embriöes somáticos da cv. Ouro em meio $1 / 2 \mathrm{MS}$; a) ausência de histodiferenciaçäo da protoderme, procambio e meristema apical; b) região basal do embriäo somático mostrando regiäo meristemática, possívelmente indicando diferenciação do meristema apical caulinar; c-d) embrião somático da cv. Nanicão em meio $\mathrm{SH}$, mostrando células altamente vacuolizadas, com grandes espaços intercelulares e, numa pequena área basal (ponta de seta), células adensadas, porém sem diferenciação de tecidos. Barras $=100 \mu \mathrm{m}(7 \mathrm{a}-\mathrm{d})$. 
O percentual de explantes responsivos com formação de estruturas embriogênicas foi alta em todos os tratamentos e cultivares, chegando a $90 \%$ no período de 4 semanas (Tab. 7). No entanto, a conversão dos embriões somáticos em plântulas não foi obtida. Na repetição do experimento, observouse uma diminuição de resposta embriogênica, com um máximo de $79 \%$ após 4 semanas de indução (Tab. 8).

Tabela 8. Percentual de resposta de formação de estruturas embriogênicas em ápices vegetativos de Musa spp, cultivados em diferentes meios suplementados com $10 \mu \mathrm{M}$ dicamba, por quatro semanas.

\begin{tabular}{ccc}
\hline Cultivar & Tratamentos & Resposta embriogênica (\%) \\
\hline \multirow{3}{*}{ Nanicão } & FN-Lite & $72,7 \pm 1,33$ \\
& SH & $78,0 \pm 1,33$ \\
& $1 / 2$ MS & $78,4 \pm 1,33$ \\
& & \\
\multirow{4}{*}{ Ouro } & FN-Lite & $79,1 \pm 1,00$ \\
& SH & $67,3 \pm 1,38$ \\
& $1 / 2$ MS & $75,4 \pm 1,36$ \\
\hline
\end{tabular}

Verificou-se também, uma similaridade na quantidade de resposta entre as duas cultivares, porém explantes da cv. Ouro em meio $\mathrm{SH}$, tiveram o menor percentual de resposta (67\%) (Tab. 8). As estruturas embriogênicas formadas foram transferidas para meio FN-Lite sem reguladores vegetais, porém, novamente observou-se somente o desenvolvimento do ápice radicular, sem regeneração em plântula. 


\subsubsection{Maturação e germinação dos embriōes somáticos.}

Os explantes das cvs. Ouro e Nanicão em meio de indução (MS, $1 / 2$ MS ou FN-Lite, acrescidos de $10 \mu \mathrm{M}$ de dicamba) responderam com a formação de calos embriogênicos e embriões somáticos, sendo transferidos após 30 dias, para meio de maturação. Após 4 a 7 dias observou-se, em alguns casos, a oxidação do material in vitro. Durante o periodo de cultivo em meio de maturação, os calos embriogênicos apresentaram assincronia no desenvolvimento de embriões somáticos. A maioria deste embriões, mostraram crescimento preferencial do ápice radicular (Fig. 8b), logo na primeira semana de maturação. Caracteristica semelhante, também foi observada por Banerjee et al. (1987) em embriões somáticos de Musa, cv. Bluggoe, em meio de indução com 2,4-D. Segundo os autores, a embriogênese somática foi incompleta, com alteração morfológica do desenvolvimento dos embriões somáticos, favorecendo a formação do ápice radicular, porém, com uma possível repressão do meristema caulinar. Associado a isso, observa-se que embriões somáticos, geralmente, têm a forte tendência de formar raizes, porém, baixa habilidade de formar parte aérea (Novak et al., 1989).

No entanto, também foi observado que alguns embriões somáticos, permaneceram em estágio de quiescência, ou seja, a paralização do seu crescimento, nas duas primeiras semanas de maturação. Estes embriões, após cultivo em meio de maturação (Fig. 8a), apresentaram formação semelhante aos embriões zigóticos, com aparecimento primeiramente do ápice caulinar, seguido do ápice radicular, conforme descrito por Raghavan \& Sharma (1995). Esta paralização inicial dos embriōes somáticos, possivelmente, favoreceu um desenvolvimento mais sincronizado do embrião, possibilitando 0 estabelecimento do meristema caulinar. Estes embriões, completaram o processo de germinação, convertendo-se em plântulas (Fig. 8c). 

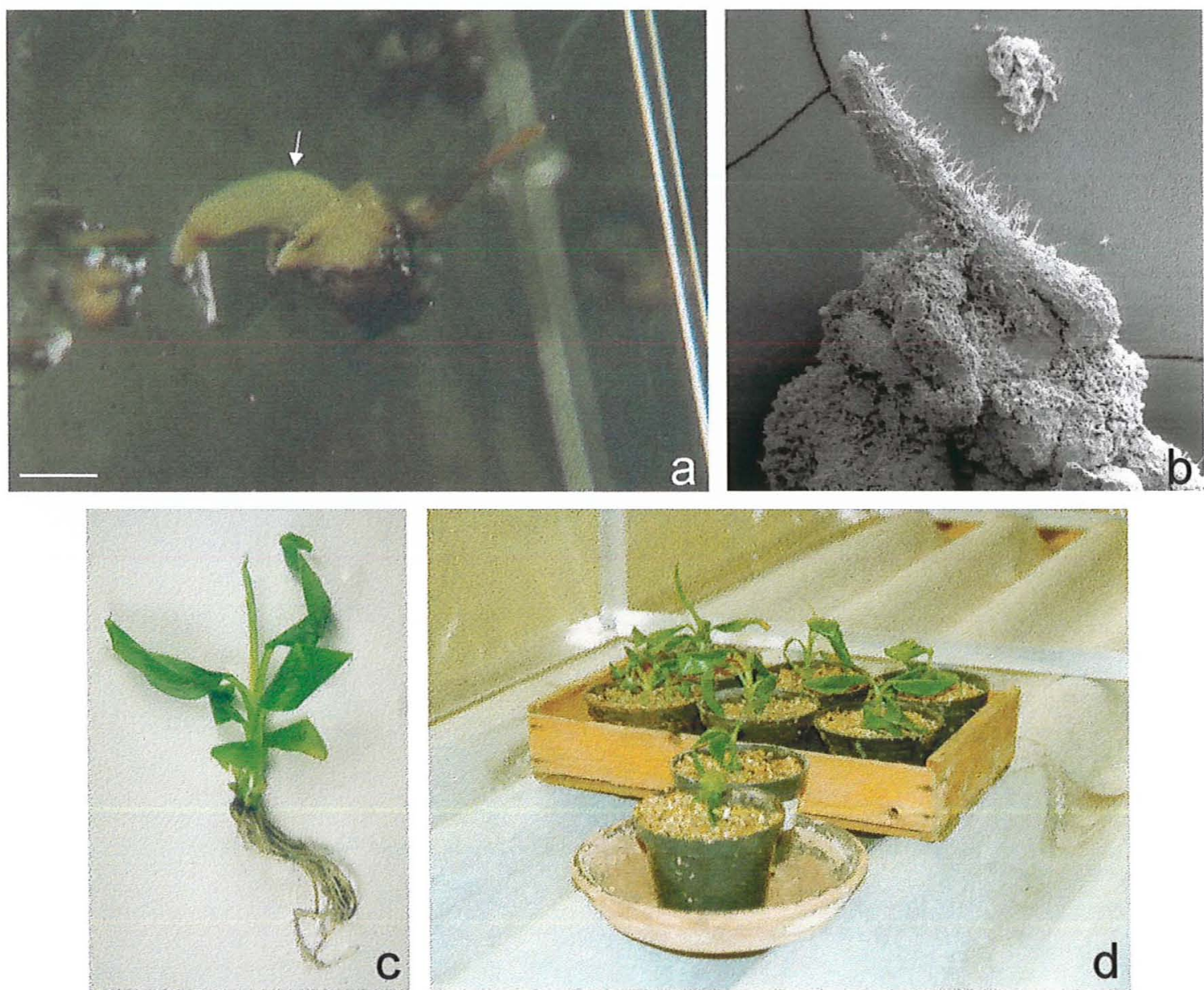

Figura 8. Embriōes somáticos e plântulas obtidas a partir de ápice vegetativo de Musa spp. a-b) embriões somáticos após cultivo em meio de maturação; a) embrião somático em início da germinação, nota-se o crescimento do ápice caulinar, com primórdio foliar desenvolvido (seta); b) micrografia de MEV mostrando embrião somático com desenvolvimento pronunciado da raiz; c) plântula da cv. Nanicão obtida a partir de embriōes somáticos; d) plântulas das cvs. Ouro e Nanicão em fase de aclimatação. Barra = 1 mm (8a). 
Após a maturação, os embriões somáticos foram transferidos para meio de desenvolvimento FN-Lite sem reguladores vegetais. Alguns embriōes, permanecendo no escuro, oxidaram-se, sendo o restante transferido após 4 dias, para condições de $16 \mathrm{~h}$ de fotoperíodo, porém, em baixa luminosidade. Aqueles embriões que apresentavam crescimento do ápice caulinar e do primórdio foliar, após transferência para meio de desenvolvimento e meio de germinação, apresentaram continuidade de crescimento, convertendo-se em plântulas (Fig. 8c) (Tab. 9).

Tabela 9. Efeito dos tratamentos de indução e maturação em Musa spp, para obtenção de embriões somáticos, germinação e conversão em plântulas, utilizando ápice vegetativo como explantes.

\begin{tabular}{|c|c|c|c|c|c|}
\hline \multirow[t]{2}{*}{ Cultivar } & \multicolumn{5}{|c|}{ Meio de Cultivo } \\
\hline & Indução & Maturação & Desenvol/to & Germinação & Conversão \\
\hline Ouro & FN-Lite & M1 & FN básico & - & $-\cdots$ \\
\hline Ouro & FN-Lite & M2 & FN básico & -- & -- \\
\hline Ouro & MS & M1 & FN básico & -- & -- \\
\hline Ouro & MS & M2 & FN básico & 2 & 2 \\
\hline Ouro & $1 / 2 M S$ & M1 & FN básico & 1 & 1 \\
\hline Ouro & $1 / 2 M S$ & M2 & FN básico & -- & -- \\
\hline Nanicão & FN-Lite & M1 & FN básico & 2 & 2 \\
\hline Nanicão & MS & M2 & FN básico & 2 & 2 \\
\hline Nanicão & $1 / 2 M S$ & M2 & FN básico & 1 & 1 \\
\hline
\end{tabular}


O cultivo de embriões somáticos de Musa spp em meio de maturação, contendo alto potencial osmótico através da utilização da concentração elevada de sacarose (60 g/L) ou do uso de polietilenoglicol (PEG), possivelmente, contribuiu com uma sincronia no desenvolvimento de alguns embriões somáticos, permitindo a conversão em plântulas, porém, em baixo percentual (Tab. 9). Mesmo obtendo reduzido número de plântulas, verifica-se que através da maturação é possível a conversão dos embriões somáticos de Musa spp em plântulas.

As plântulas obtidas foram aclimatadas (Fig. 8d) para plantio no campo, e possível avaliação de suas características morfológicas.

\subsection{Embriogênese somática a partir de inflorescência funcionalmente masculinas}

Os botões florais funcionalmente masculinos de bananeira, cultivares Nanicão Jangada e Grand Nain, induzidos em fotoperíodo de 16 horas, ficaram oxidados ou esverdeados após 2 meses de cultivo (Fig. 9a), apresentando intumescimento dos botões florais e não apresentando a formação de calos ou estruturas embriogênicas (Tab. 10), indicando que a luz não propicia condições adequadas para a indução da embriogênese somática nestas cultivares, diferindo do relato feito por Escalant et al. (1994), os quais obtiveram elevada resposta embriogênica na cV. Grand Nain sob condições de 16 horas de fotoperíodo. No tratamento de indução no escuro, os explantes de 'Nanicão Jangada' responderam após 2 a 3 meses de cultivo em meio de indução, MI, formando calos embriogênicos de coloração amarelada e esbranquiçada na superficie dos botões florais (Fig. 9b). Nos explantes da cultivar Grand Nain porém, observou-se elevada oxidação ou formação de calos de aparência nãoembriogênica, de aspecto friável e translúcido, não tendo se observado a formação de calos embriogênicos (Tab. 10). Navarro et al. (1997), obtiveram a 
partir de inflorescência masculinas de Musa cv. Grand Nain, 2 a 6\% de explantes com formação de calos embriogênicos e formação de embriões somáticos em meio de proliferação, com reduzida concentração de 2,4-D. Escalant et al. (1994), observaram melhor formação de embriōes somáticos na cv. Grand Nain, mas baixa resposta na cv. Pelipita, do grupo ABB, também indicando que a capacidade embriogênica é dependente do genótipo.

Tabela 10. Frequência de resposta embriogênica em explantes de bananeira, cultivares Grand Nain e Nanicão Jangada sob diferentes condições de cultivo.

\begin{tabular}{|c|c|c|c|c|c|c|}
\hline \multirow[t]{2}{*}{ Cultivar } & \multirow[t]{2}{*}{ Fotoperíodo } & \multirow{2}{*}{$\begin{array}{c}\text { Meio } \\
\text { de cultura }\end{array}$} & \multicolumn{4}{|c|}{ Resposta embriogênica (\%) } \\
\hline & & & $E$ & $\mathrm{CE}$ & CNE & 0 \\
\hline Grand Nain & $16 \mathrm{~h}\left(4 \mu \mathrm{mol} \mathrm{m} \mathrm{m}^{-2} \mathrm{~s}^{-1}\right)$ & MI & 0 & 0 & 0 & 100 \\
\hline Grand Nain & Escuro & MI & 0 & 0 & 28 & 72 \\
\hline Nanicão Jangada & $16 \mathrm{~h}\left(4 \mu \mathrm{mol} \mathrm{m}^{-2} \mathrm{~s}^{-1}\right)$ & MI & 0 & 0 & 0 & 100 \\
\hline Nanicão Jangada & Escuro & Ml e MG & 6 & 23 & 39 & 32 \\
\hline
\end{tabular}

$\mathrm{Na}$ cv. Nanicão Jangada, notou-se que cerca de 3 a 4 semanas após a indução, os explantes já apresentavam algumas alterações morfológicas, como ligeiro intumescimento dos botões florais e alteração da coloração de branca para amarelada.

Após cinco meses em meio $\mathrm{MI}$, os explantes que apresentaram alterações morfológicas foram transferidos para meio MG, permanecendo por mais 2 meses. Durante os sete meses de cultivo, diversas alterações foram observadas nos explantes, desde oxidação, formação de calos embriogênicos ou não embriogênicos, continuidade de desenvolvimento dos botões florais e formação de embriões somáticos. 

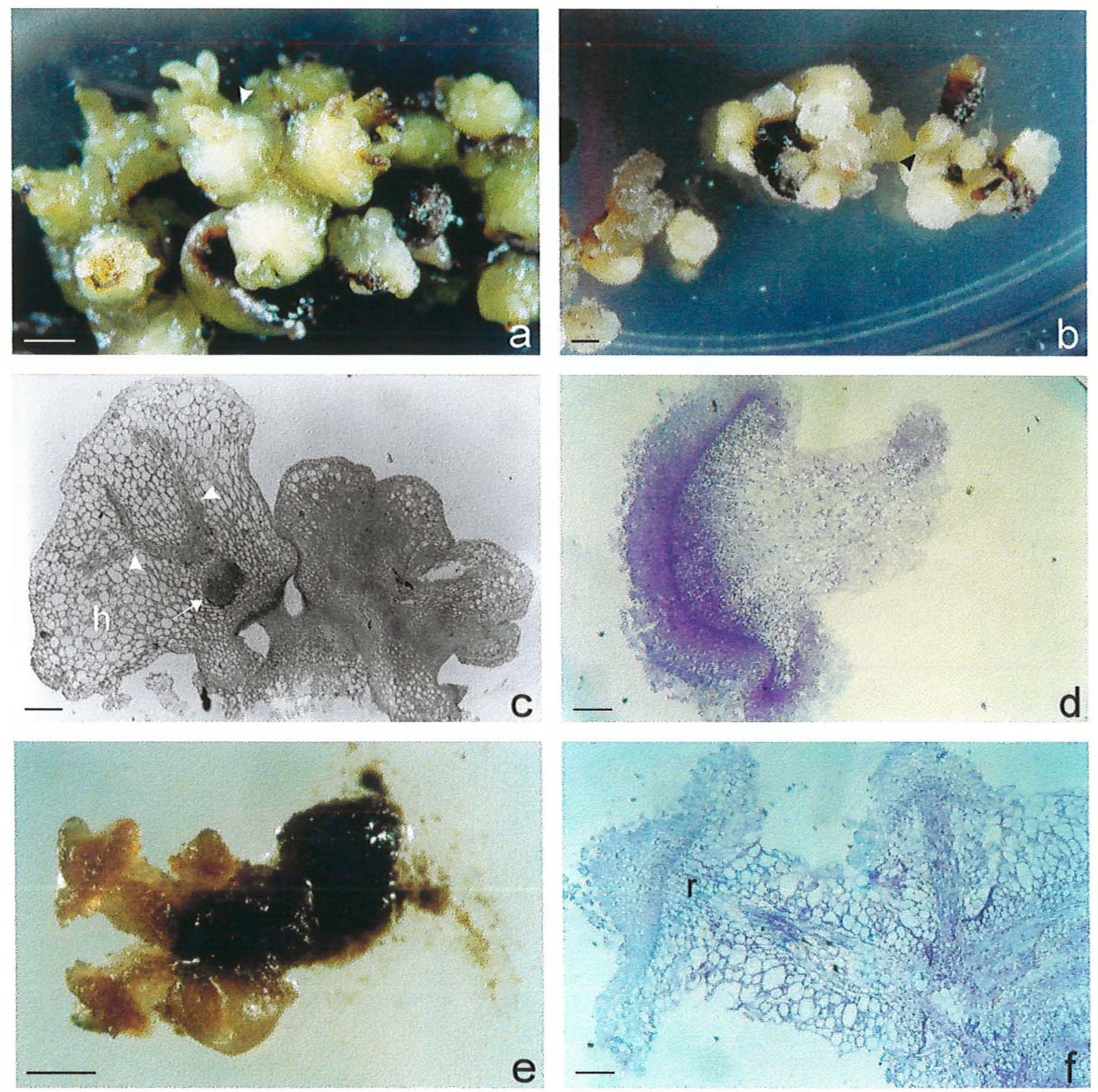

Figura 9. Cultivo in vitro de dicásios do setor ândrico de Musa spp, cv. Nanicão Jangada. a) explantes dois meses após a induçăo no meio de cultura em condições de $16 \mathrm{~h}$ de fotoperíodo, mostrando intumescimento dos botōes florais (ponta de seta), coloração esverdeada dos tecidos e ausência de formação de calo; b) explantes após dois meses em meio de indução no escuro, mostrando calo embriogênico e embriöes somáticos (ponta de seta); c-d) seção longitudinal dos embriōes somáticos do tipo cogumelo após 7 meses de cultivo no escuro, apresentando semelhança com embriäo zigótico de Musa acuminata; c) diferenciação do eixo embrionário (seta) e dos cordöes procambiais (ponta de seta) na região do haustório $(h)$; d) variação do tipo de embrião somático na Fig. 9c, com ausência de formação dos meristemas apicais, procâmbio e protoderme; e) estruturas monopolares semelhantes a raízes conectadas ao explante; f) seção longitudinal das estruturas monopolares da figura $9 \mathrm{e}$, podendo-se observar o meristema apical radicular $(r)$ e a conexão vascular com o tecido do explante. Barras $=1 \mathrm{~mm}(9 \mathrm{a}, \mathrm{b}, \mathrm{e}) ; 200 \mu \mathrm{m}(9 \mathrm{c}, \mathrm{d}, \mathrm{f})$. 
A embriogênese somática caracterizou-se por assincronia no desenvolvimento dos embriōes somáticos, além do aparecimento de 2 tipos de embriões somáticos com características morfológicas distintas. Um tipo de embrião somático apresentava-se como estrutura do tipo "cogumelo", semelhante a embriōes zigóticos de Musa acuminata (AA) (McGahan, 1961), e Musa balbisiana (BB) (Escalant \& Teisson, 1987). O segundo tipo morfológico, caracterizou-se pela formação de embriões somáticos mais alongados, semelhantes a embriões zigóticos de outras monocotiledôneas.

Cortes histológicos dos embriōes somáticos do tipo "cogumelo" (Fig. $9 \mathrm{c}, \mathrm{d})$, revelaram duas estruturas anatômicas distintas. Alguns destes embriões (Fig. 9c) apresentavam uma região apical constituída pelo haustório (ha) (parte principal do cotilédone), e uma região basal sede do futuro eixo embrionário. As regiões apical e basal estavam conectadas por cordões procambiais. Este tipo morfológico, apresenta características anatômicas semelhantes aos embriões zigóticos das espécies selvagens de Musa (McGahan, 1961). Variações desta estrutura anatômica apresentavam coloração amarelada e que se destacavam facilmente dos explantes, revelando porém, ausência de diferenciação dos meristemas apicais, do procâmbio e de uma protoderme definida (Fig. 9d). Também observaram-se, em alguns casos, o surgimento de estruturas monopolares, com conexão vascular com o tecido do explante, indicando a formação de raízes (Figs. 9e, f). 

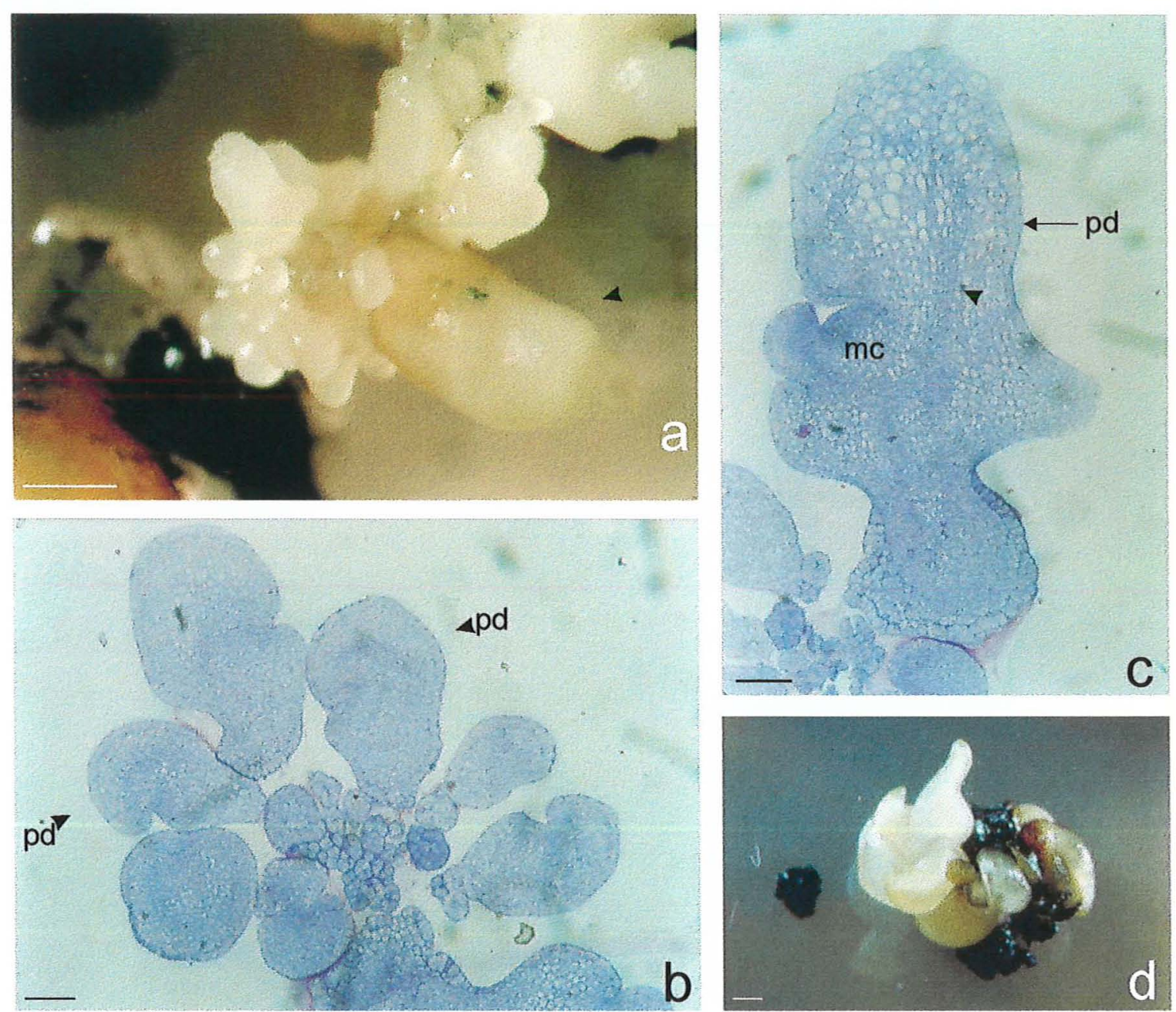

Figura 10. Embriōes somáticos de Musa spp cv. Nanicão Jangada obtidos a partir de cultura de dicásios do setor ândrico, após 7 meses de cultivo no escuro. a) embriōes somáticos formados na base de um botão floral (ponta de seta), em diversos estágios de desenvolvimento; b) cortes histológicos de embriōes somáticos, mostrando protoderme bem definida (pd); c) seção longitudinal de embrião somático bem desenvolvido, mostrando a protoderme (pd) (seta), faixa procambial (ponta de seta) e o meristema caulinar $(\mathrm{mc})$; d) botão floral de Musa spp cv. Nanicão Jangada, apresentando continuidade de desenvolvimento e assemelhando-se a um embrião em fase de germinação. Barra $=1 \mathrm{~mm}(10 \mathrm{a}-\mathrm{d},) ; 100 \mu \mathrm{m}(10 \mathrm{~b}-\mathrm{c})$. 
Em menor frequência, verificou-se na superficie dos explantes o segundo tipo morfológico de embriões somáticos, mais alongados, apresentando uma chanfradura lateral, onde se localiza o meristema caulinar (Figs. 10a,c e 11a,b), assemelhando-se a embriōes zigóticos de outras monocotiledôneas. Através de análise histológica dessas estruturas formadas na base do botão floral (Fig. 10a), identificaram-se embriões somáticos em diferentes fases de desenvolvimento (Fig. 10b) e embriões mais desenvolvidos (Fig. 10c) apresentando, desde o estágio globular, uma protoderme definida caracterizada por uma camada de células justapostas. No embrião mais desenvolvido (Fig. 10c), observaram-se as faixas procambiais e o meristema caulinar. Este tipo de embrião somático assemelha-se àqueles apresentados em culturas embriogênicas de Musa spp por Escalant et al. (1994) e Navarro et. al. (1997).

Uma variação deste tipo de embrião somático, com formato ligeiramente mais arredondado (Figs. 11a,b), foi também observada. Cortes histológicos seriados mostraram que esses embriōes apresentavam protoderme definida (Fig. 11b), o início de formação de uma região procambial e uma chanfradura lateral, com o início de diferenciação do meristema caulinar. Cronauer-Mitra \& Krikorian (1988), também obtiveram embriões somáticos com este tipo de morfologia, originários do cultivo in vitro de embriões zigóticos de uma espécie ornamental, Musa ornata Roxb.

Em vários explantes em meio de indução, foi também observada uma continuidade no desenvolvimento dos botões florais. Pelas caracteristicas morfológicas, essas estruturas podem ser confundidas com embriões somáticos iniciando o processo de germinação (Figura 10d).

A transferência dos embriões somáticos para meio de subcultivo MG, independente do tipo morfológico, não proporcionou uma continuidade no desenvolvimento, observando-se somente oxidação gradual dos mesmos, não tendo sido possivel a conversão de embriões em plantas, nas condições de 
cultivo testadas.

Nos trabalhos envolvendo a embriogênese somática em Musa spp, não há relatos de evidências de diferenças morfológicas entre os embriões somáticos produzidos sob as mesmas condições de cultivo (Marroquin et al., 1993; Banerjee et al., 1987; Cronauer-Mitra \& Krikorian, 1988). Megia et al. (1993) e Lee et al. (1997), apresentam figuras de embriōes somáticos com caracteristicas morfológicas semelhantes aos embriões zigóticos de Musa acuminata, enquanto que Cronauer-Mitra \& Krikorian (1988), Escalant et al. (1994) e Navarro et al. (1997) apresentam micrografias de embriões somáticos alongados. Os resultados obtidos neste trabalho, indicam que em um único protocolo de embriogênese somática na cultura da bananeira e com a mesma cultivar, podem-se identificar embriōes somáticos com características morfológicas diferentes. Vale ressaltar que embriões somáticos com caracteristicas morfológicas distintas podem ser observados nos relatos dos autores acima mencionados, porém a presença de ambas as formas em uma só cultivar de Musa spp, ou em um mesmo protocolo de obtenção de embriogênese somática, não havia sido relatada.

Em relação ao número total de explantes introduzidos da cultivar Nanicão Jangada, verificou-se o intumescimento dos explantes seguido de formação de calos embriogênicos ou não embriogênicos porém, verificou-se uma reduzida porcentagem de diferenciação de embriōes somáticos (Tab. 10) apresentando, em sua maioria, o formato de "cogumelo" com coloração amarelada (Fig. 9b). 

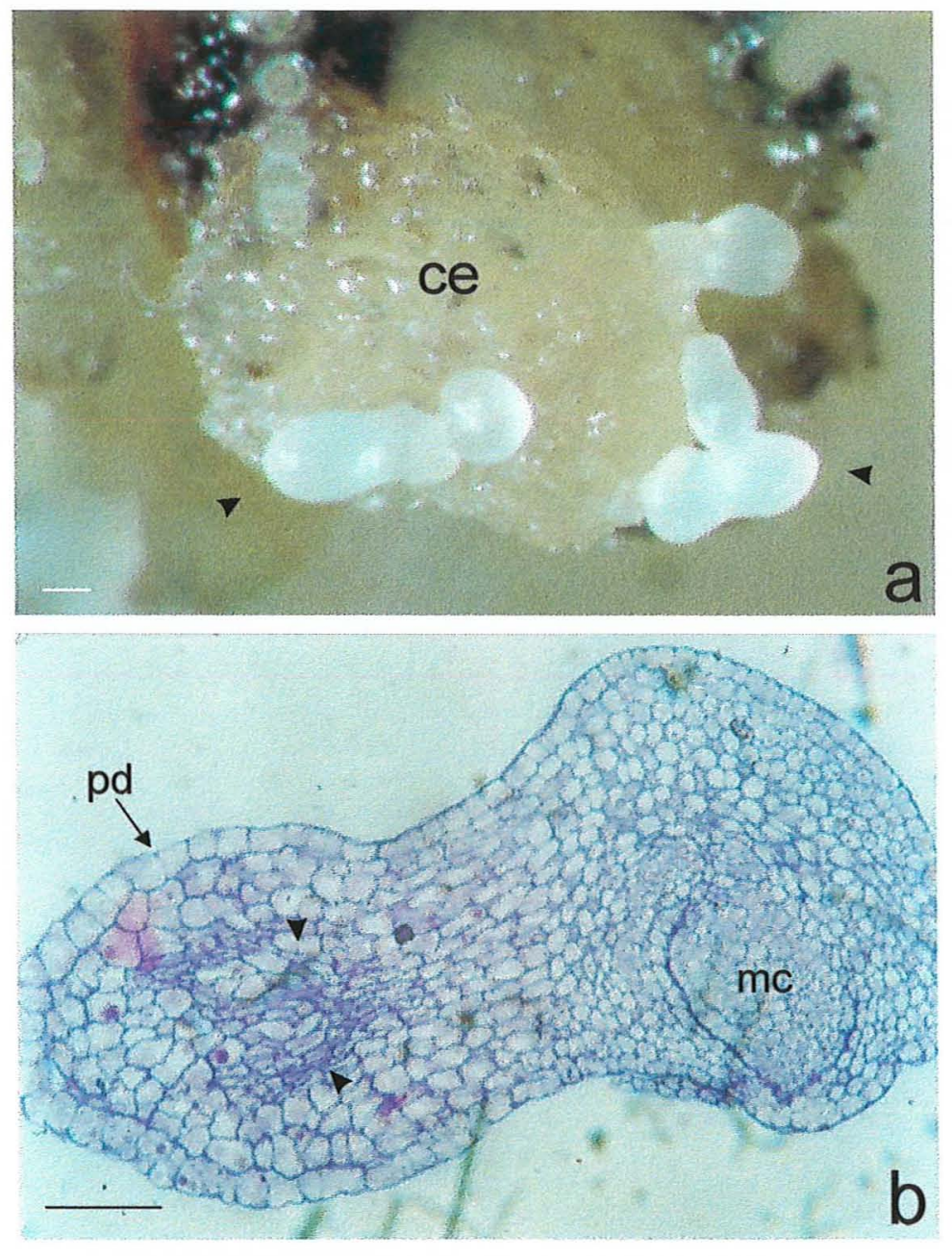

Figura 11. Embriöes somáticos de Musa spp cv. Nanicão Jangada obtidos a partir de cultura de dicásios do setor ândrico, após 7 meses de cultivo no escuro a) embriöes somáticos (ponta de seta) formados a partir de calo embriogênico (ce); b) seção longitudinal do embrião somático evidenciando o início de formação do procâmbio (ponta de seta), meristema caulinar $(\mathrm{mc}$ ) e protoderme (pd) (seta) bem definida. Barras $=200 \mu \mathrm{m}$ (11a); $100 \mu \mathrm{m}(11 \mathrm{~b})$. 


\section{CONCLUSÕES}

Os resultados obtidos permitiram concluir que as auxinas picloram e dicamba foram eficientes para a indução de embriogênese somática em explantes de ápice vegetativo de bananeira cv. Nanicão, enquanto que NAA e 2,4-D, nas concentrações testadas, não foram eficientes. Análises histológicas mostraram pró-embriōes, os quais deram origem a embriōes zigóticos morfologicamente semelhantes a embriôes zigóticos de Musa acuminata, porém com ausência de histodiferenciação.

$\mathrm{O}$ uso de meios de cultura com diferentes relações $\mathrm{NO}_{3}^{-}: \mathrm{NH}_{4}^{+}(1 / 2 \mathrm{MS}$, FN-Lite e $\mathrm{SH}$ ), acrescidos de dicamba, resultou em diferenças na qualidade dos embriōes, sendo que os meios 1/2 MS e FN-Lite apresentaram caracterísiticas anatômicas mais semelhantes aos embriões zigóticos, porém com ausência de diferenciação de protoderme, meristemas apicais e procâmbio.

Tratamentos com elevada concentração de sacarose, ou com PEG, visando a maturação dos embriões somáticos, permitiram a conversão de embriōes em plantas, porém, em baixa frequência. Embriōes com desenvolvimento apenas do polo radicular, foram observados em alta frequência.

O uso de inflorescências masculinas como explante, permitiu a formação de calos embriogênicos e não embriogênicos, formação de embriões somáticos, continuidade no desenvolvimento do botão floral ou oxidação do explante. Análises morfo-anatômicas dos embriões somáticos, mostraram características distintas: uma semelhante ao embrião zigótico de Musa 
acuminata e, em menor frequência, embriōes somáticos semelhantes a embriōes zigóticos de outras monocotiledôneas, indicando que em um único protocolo de embriogênese somática, é possivel ocorrer a formação de diferentes padrões morfológicos de embriões somáticos. 


\section{REFERÊNCIAS BIBLIOGRÁFICAS}

ALEMANNO, L.; BERTHOULY, M.; MICHAUX-FERRIERE, N. A comparison between Theobroma cacao L. zygotic embryogenesis and somatic embryogenesis from floral explants. InVitro Cellular and Developmental Biology-Plant, v.33, p.163-172, 1997.

AMMIRATO, P.V. Patterns of development in culture. In: HENKE, R.R.; HUGHES, K.W.; COSNTANTIN, M.J.; HOLLAENDER, A.; WILSON, C.M. (Ed.) Tissue culture in forestry and agriculture. New York: Plenum, 1985. p.9-29.

ATTREE, S.M.; DUNSTAN, D.I.; FOWKE, L.C. White spruce (Picea glauca Moench) Voss and black spruce (Picea mariana) Mill B.S.P. In: BAJAJ, Y.P.S. (Ed.) Trees. Berlin: Springer-Verlag, $1991 . \quad$ p.423-445. (Biotechnology in Agriculture and Forestry, 1).

ATTREE, S.M.; FOWKE, L.C. Embryogeny of gymnosperms: advances in synthetic seed technology of conifers. Plant Cell, Tissue and Organ Culture, v.35, p.1-35, 1993.

BANERJEE, N.; SCHOOFS, J.; HOLLEVOET, S.; DUMORTIER, F.; DE LANGHE, E. Aspects and prospects of somatic embryogenesis in Musa, ABB, cv. Bluoggoe. Acta Horticulturae, n.212, p.727-730, 1987. 
BEWLEY, J.D.; BLACK, M. Seeds: physiology of development and germination. New York: Plenum Press, 1994. cap.1, p.1-33: Seeds: germination, structure and composition.

BUCHHEIM, J.A.; COLBURN, S.M.; RANCH, J.P. Maturation of soybean somatic embryos and the transition to plantlet growth. Plant Physiology, v.89, p.768-775, 1989.

CAPUANA, M.; DEBERGH, P.C. Improvement of the maturation and germination of horse chestnut somatic embryos. Plant Cell, Tissue and Organ Culture, v.48, p.23-29, 1997.

CÔTE, F.X.; DOMERGUE, R.; MONMARSON, S.; SCHWENDIMAN, J.; TEISSON, C.; ESCALANT, J.V. Embryogenic cell suspensions from the male flower of Musa AAA cv. Grand Nain. Physiologia Plantarum, v.97, p.285-290, 1996.

CRONAUER, S.; KRIKORIAN, A.D. Somatic embryos from cultured tissues of triploid plantains (Musa 'ABB'). Plant Cell Reports, v.2, p.289-291, 1983.

CRONAUER-MITRA, S.S.; KRIKORIAN, A.D. Plant regeneration via somatic embryogenesis in the seeded diploid banana Musa ornata Roxb. Plant Cell Reports, v.7, p.23-25, 1988.

DHED'A, D.; DUMORTIER, F.; PANIS, B.; VUYLSTEKE, D.; DE LANGHE, E. Plant regeneration in cell suspension cultures of cooking banana $\mathrm{CV}$. Bluggoe (ABB group). Fruits, v.46, p.125-135, 1991. 
DE KLERK, G.J.; ARNHOLDT-SCHMITT, B.; LIEBEREI, R.; NEUMANN, K.H. Regeneration of roots, shoots and embryos: physiological, biochemical and molecular aspects. Biologia Plantarum, v.39, p.53-66, 1977.

ESCALANT, J.V.; TEISSON, C. Comportments in vitro de l'embryon isolé du bananier (Musa species). Fruits, v.42, p.333-342, 1987.

ESCALANT, J.V.; TEISSON, C. Somatic embryogenesis and plants from immature zygotic embryos of the species Musa acuminata and Musa balbisiana. Plant Cell Reports, v.7, p.665-668, 1989.

ESCALANT, J.V.; TEISSON, C.; COTE, F. Amplified somatic embryogenesis from male flowers of triploid banana and plantain cultivars (Musa spp.). In Vitro Cellular and Developmental Biology- Plant, v.30, p.181-186, 1994.

FEDER, N.; O'BRIEN, T.P. Plant microtechnique: some principles and new methods. American Journal of Botany, v.55, p.123-142, 1968.

FINER, J.J.; NAGASAWA, A. Development of an embryogenic suspension culture of soybean (Glycine max Merrill.). Plant Cell, Tissue and Organ Culture, v.15, p.125-136, 1988.

FISCHER, C.; NEUHAUS, G. Influence of auxin on the establishment of bilateral symmetry in monocots. The Plant Journal, v.9, p.659-669, 1996.

FNP CONSULTORIA \& COMÉRCIO. Agrianual 2000. São Paulo, 1999. p.194-200: Banana: a qualidade em primeiro lugar. 
FUJII, J.A.A.; SLADE, D.; OLSEN, R.; RUZIN, S.E.; REDENBAUGH, K. Alfafa somatic embryo maturation and conversion to plants. Plant Science, v.72, p.93-100, 1990.

GOH, D.K.S.; MICHAUX-FERRIERE, N.; MONTEUUIS, A.; BON, M.C. Evidence of somatic embryogenesis from root tip explants of the rattan Calamus manan. InVitro Cellular and Developmental Biology- Plant, v.35, p.424-427, 1999.

GRATTAPAGLIA, D.; MACHADO, M.A. Micropropagação. In: TORRES, A.C.; CALDAS, L.S.; BUSO, J.A. (Ed.). Cultura de tecidos e transformação genética de plantas. Brasilia: Embrapa,SPI, 1998. parte II, p.183-260.

HALPERIN, W.; WETHERELL, D.F. Adventive embryony in tissue cultures of the wild carrot, Dacus carota. American Journal of Botany, v.51, p.274283, 1964.

LEE, K.S.; ZAPATA-ARIAS, F.J.; BRUNNER, H.; AFZA, R. Histology of somatic embryo initiation and organogenesis from rhizome explants. Plant Cell, Tissue and Organ Culture, v.51, p.1-8, 1997.

LEMOS, O.F. Embriogênese somática em três cultivares de bananeira (Musa spp., Grupos AAA e AAB). Piracicaba, 1994 104p. Tese (Mestrado) Escola Superior de Agricultura "Luiz de Queiroz"- Universidade de São Paulo. 
LI, X.Y.; HUANG, F.H.; MURPHY, J.B.; GBUR JUNIOR, E.E. Polyethlene glycol and maltose enhance somatic embryo maturation in loblolly pine (Pinus taeda L.). In Vitro Cellular and Developmental Biology-Plant, v.34, p.22-26, 1998.

LIU, C.M.; XU, Z.H.; CHUA, N.H. Auxin polar transport is essential for the establishment of bilateral symmetry during early plant embryogenesis. Plant Cell, v.5, p.621-630, 1993.

McGAHAN, M.W. Studies on the seed of banana. I. Anatomy of the seed and embryo of Musa balbisiana. American Journal of Botany, v.48, p.230-238, 1961.

MAHESWARAN, G.; WILLIAMS, E.G. Origin and development of somatic embryoides formed directly on immature embryos of Trifolium repens in vitro. Annals of Botany, v.56, p.619-630, 1985.

MARROQUIN, C.G.; PADUSCHECK, C.; ESCALANT, J.V.; TEISSON, C. Somatic embryogenesis and plant regeneration through cell suspensions in Musa acuminata. In Vitro Cellular and Developmental Biology-Plant, v.29, p.43-46, 1993.

MAY, G.D.; AFZA, R.; MASON, H.S.; WIECKO, A.; NOVAK, F.J.; ARNTZEN, C.J. Generation of transgenic banana (Musa acuminata) plants via agrobacterium-mediated transformation. Bio/Technology, v.13, p.486-492, 1995. 
MEIJER, E.G.M.; BROWN, D.C.W. Role of exogenous reduced nitrogen and sucrose in rapid high frequency somatic embryogenesis in Medicago sativa. Plant Cell, Tissue and Organ Culture, v.10, p.11-19, 1987.

MENDES, B.J.; MENDES, F.J.; TULMANN NETO, A.; DEMÉTRIO, C.G.B.; PIESKE, O.R. Efficacy of banana plantlet production by micropropagation. Pesquisa Agropecuária Brasileira, v.31, p.863-867, 1996.

MENDES, B.J.; FILIPPI, S.B.; DEMÉTRIO, C.G.B.; RODRIGUEZ, A.P.M. A statistical approach to study the dynamics of micropropagation rates, using banana (Musa spp) as an example. Plant Cell Reports, v.18, p.967-971, 1999.

MERKLE, S.; PARROTT, W.; FLINN, B. S. Morphogenic aspects of somatic embryogenesis. In: THORPE, T.A. (Ed.) In vitro embryogenesis in plants. Dordrecht: Kluwer Academic, 1995. p.155-203.

MICHAUX-FERRIĖRE, N.; CARRON, M.-P. Histology of early somatic embryogenesis in Hevea brasiliensis: The importance of timing of subculturing. Plant Cell, Tissue and Organ Culture, v.19, p.234-256, 1989.

MICHAUX-FERRIĖRE, N.; SCWENDIMAN, J. Histology of somatic embryogenesis. In: DATTÉE, Y.; DUMAS, C.; GALLAIS, A. (Ed.) Reproductive biology and plant breeding. Springer-Verlag: BiotropCIRAD, 1992. p.247-259. 
MISRA, S.; ATTREE, S.M.; LEAL, I.; FOWKE, L.C. Effect of abscisic acid, osmoticum and desiccation on synthesis of storage proteins during the development of white spruce somatic embryos. Annals of Botany, v.71, p.11-22, 1993.

MONNIER, M. Culture of zygotic embryos. In: THORPE, T.A. (Ed) In vitro embryogenesis in plants. Dordrecht: Kluwer Academic, 1995. p.117-153.

MURASHIGE, T.; SKOOG, F. A revised medium for rapid growth and bioassays with tobacco tissue cultures. Physiologia Plantarum, v.15, p.473-497, 1962.

NAVARRO, C.; ESCOBEDO, R.M.; MAYO, A. In vitro plant regeneration from embryogenic cultures of a diploid and a triploid, Cavendish banana. Plant Cell, Tissue and Organ Culture, v.51, p.17-25, 1997.

NICKLE, T.C.; YEUNG, E.C. Failure to establish a functional shoot meristem may be a cause of conversion failure in somatic embryos of Daucus carota (Apiaceae). American Journal of Botany, v.80, p.1284-1291, 1993.

NOGUEIRA, E.M.C.; FERRARI, J.T. Doenças da bananeira. In: CICLO DE PALESTRAS SOBRE A CULTURA DA BANANEIRA, São Paulo, 1994. Anais. São Paulo: Instituto Biológico, 1994. p.37-50.

NOMURA, K.; KOMAMINE, A. Physiological and biochemical aspects of somatic embryogenesis. In: THORPE, T.A. (Ed) In vitro embryogenesis in plants. Dordrecht: Kluwer Academic, 1995. p.249-265. 
NOVAK, F.J.; AFZA, R.; VAN DUREN, M.; PEREA-DALLOS, M.; CONGER, B.V.; XIALANG, T. Somatic embryogenesis and plant regeneration in suspension cultures of dessert (AA and $A A A)$ and cooking (ABB) bananas (Musa spp). Bio/Technology, v.7, p.154-159, 1989.

PADMANABHAN, K.; CANTLIFFE, D.J.; HARRELL, R.C.; MCCONNELL, D.B. A comparison of sweet potato Ipomoea batatas (L.) Lam. using computer vision and histological analyses. Plant Cell Reports, v.17, p.685-692, 1998.

PARROTT, W.A.; DRYDEN, G.; VOGT, S.; HILDEBRAND, D.F.; COLLINS, G.B.; WILLIAMS, E.G. Optimization of somatic embryogenesis and embryo germination in soybean. In Vitro Cellular and Developmental BiologyPlant, v.24, p.817-820, 1988.

PLOETZ, R.C.; HERBERT, J.; SEBASIGARI, K.; HERNANDEZ, J.H.; PEGG, K.G.; VENTURA, J.A.; MAYATO, L.S. Importance of Fusarium wilt in different banana-growing regions. In: PLOETZ, R.C. (Ed.) Fusarium wilt of banana. St. Paul: APS Press, 1993. p.9-26.

ROBERTS, D.R.; FLINN, B.S.; WEBB, D.T.; WEBSTER, F.B.; SUTTON, C.S. Abscisic acid and indole-3-butyric acid regulation of maturation and accumulation of storage proteins in somatic embryos of interior spruce. Physiologia Plantarum, v.78, p.355-360, 1990. 
RODRIGUES, P.H.V. Efeito do número de subcultivos, na ocorrência de variação somaclonal, em mudas de bananeira micropropagadas, das cultivares Nanicão e Grand Nain. Piracicaba, 1996. 104p. Tese (Doutorado) - Escola Superior de Agricultura "Luiz de Queiroz", Universidade de São Paulo.

RODRIGUEZ, A.P.M.; WETZSTEIN, H.Y. The effect of auxin type and concentration on pecan (Carya illinoinensis) somatic embryo morphology and subsequent conversion into plants. Plant Cell Reports, v.13, p.607$611,1994$.

RODRIGUEZ, A.P.M.; WETZSTEIN, H.Y. A morphological and histological comparison of the initiation and development of pecan (Carya illinoinensis) somatic embryogenic cultures induced with naphthaleneacetic acid or 2,4dichlorophenoxyacetic acid. Protoplasma, v.204, p.71-83, 1998.

RUGGIERO, C.; GOTTARDI, M.V.C.; NOGUEIRA FILHO, G. Propagação rápida da bananeira. In: CICLO DE PALESTRAS SOBRE A CULTURA DA BANANEIRA, São Paulo, 1994. Anais. São Paulo: Instituto Biológico, 1994. p.37-50.

SAMOYLOV, V.M.; TUCKER, D.M.; PARROTT, W.A. Soybean [Glycine max (L.) merrill] embryogenic cultures: The role of sucrose and total nitrogen content on proliferation. In Vitro Cellular and Developmental BiologyPlant, v.34, p.8-13, 1998.

SCHENK, R.U.; HILDEBRANDT, A.C. Medium and techniques for induction and growth of monocotyledonous and dicotyledonous plant cell cultures. Canadian Journal of Botany, v.50, p.199-204, 1972. 
SKIRVIN, R.M.; McPHEETERS, K.D.; NORTON, M. Sources and frequency of somaclonal variation. HortScience, v.29, p.1232-1236, 1994.

SLAWINSKA, J.; OBENDORF, R.L. Soybean somatic embryo maturation: composition, respiration and water relations. Seed Science Research, v.1, p.251-262, 1991.

SRINIVASA RAO, K.; CHACKO, E.K. Induction of growth in explanted florescence axis of banana. Current Science, v. 51, p.666-667, 1982.

STOVER, R.H.; SIMMONDS, N.W. Bananas. 3.ed. New York: John Wiley \& Sons, 1987. cap.18, p.386-395: Fruit physiology, biochemistry and nutritional values.

STUART, D.A.; NELSEN, J.; NICHOL, J.W. Expression of $7 \mathrm{~S}$ and $11 \mathrm{~S}$ alfalfa [Medicago sativa] seed storage proteins in somatic embryos. Journal of Plant Physiology, v.132, p.134-139, 1988.

TRIGIANO, R.N.; BEATY, R.M.; GRAHAM, E.T. Somatic embryogenesis from immature embryos of red bud (Cercis canadensis). Plant Cell Reports, v.7, p.148-150, 1988.

XU, N.; COUTER, K.M.; BEWLEY, J.D. Abscisic acid and osmoticum prevent germination of developing alfalfa embryos, but only osmoticum maintains the synthesis of developmental proteins. Planta, v.182, p.382-390, 1990.

YEUNG, E.C. Structural and developmental patterns in somatic embryogenesis. In: THORPE, T.A. (Ed) In vitro embryogenesis in plants. Dordrecht: Kluwer Academic, 1995. p.205-247. 
WALKER, K.A.; SATO, S.J. Morphogenesis in callus tissue of Medicago sativa: the role of ammonium ion in somatic embryogenesis. Plant Cell, Tissue and Organ Culture, v.1, p.109-121, 1981. 